\title{
Natural and human-induced hypoxia and consequences for coastal areas: synthesis and future development
}

\author{
J. Zhang ${ }^{1}$, D. Gilbert ${ }^{2}$, A. J. Gooday ${ }^{3}$, L. Levin ${ }^{4}$, S. W. A. Naqvi ${ }^{5}$, J. J. Middelburg ${ }^{6}$, M. Scranton ${ }^{7}$, W. Ekau ${ }^{8}$, \\ A. Peña ${ }^{9}$, B. Dewitte ${ }^{10}$, T. Oguz ${ }^{11}$, P. M. S. Monteiro ${ }^{12}$, E. Urban ${ }^{13}$, N. N. Rabalais ${ }^{14}$, V. Ittekkot ${ }^{8}$, W. M. Kemp ${ }^{15}$, \\ O. Ulloa ${ }^{16}$, R. Elmgren ${ }^{17}$, E. Escobar-Briones ${ }^{18}$, and A. K. Van der Plas ${ }^{19}$ \\ ${ }^{1}$ State Key Laboratory of Estuarine and Coastal Research, East China Normal University, 3663 Zhongshan Road North, \\ Shanghai 200062, China \\ ${ }^{2}$ Maurice-Lamontagne Institute, Fisheries and Oceans Canada, Mont-Joli, Quebec G5H 3Z4, Canada \\ ${ }^{3}$ National Oceanography Centre, Southampton, Empress Dock, European Way, Southampton SO14 3ZH, UK \\ ${ }^{4}$ Integrative Oceanography Division, Scripps Institution of Oceanography, 9500 Gilman Dr., La Jolla, CA 92093-0218, USA \\ ${ }^{5}$ Chemical Oceanography Division, National Institute of Oceanography, Dona Paula, Goa 403004, India \\ ${ }^{6}$ Netherlands Institute of Ecology, Centre for Estuarine and Marine Ecology, Korringaweg 7, 4401 NT Yerseke, and Faculty \\ of Geosciences, Utrecht University, P.O. Box 80021, 3508 TA Utrecht, The Netherlands \\ ${ }^{7}$ School of Marine and Atmospheric Sciences, Stony Brook University, Stony Brook NY 11794, USA \\ ${ }^{8}$ Center for Tropical Marine Ecology, Fahrenheitstrasse 6, 28359 Bremen, Germany \\ ${ }^{9}$ Institute of Ocean Sciences, Fisheries \& Oceans Canada, P.O. Box 6000, Sidney, B.C. V8L 4B2, Canada \\ ${ }^{10}$ LEGOS/IRD, 14 av. Edouard Belin, 31400 Toulouse, France \\ ${ }^{11}$ Institute of Marine Sciences, Middle East Technical University, Erdemli 33731, Turkey \\ ${ }^{12}$ Ocean Systems \& Climate Group, CSIR, P.O. Box 320, Stellenbosch 7599, South Africa \\ ${ }^{13}$ Scientific Committee on Oceanic Research, College of Earth, Ocean, and Environment, University of Delaware, Newark, \\ DE 19716, USA \\ ${ }^{14}$ Louisiana Universities Marine Consortium, 8124 Highway 56, Chauvin, LA 70344, USA \\ ${ }^{15}$ Horn Point Laboratory, University of Maryland Center for Environmental Science, P.O. Box 775, Cambridge, \\ MD 21613, USA \\ ${ }^{16}$ Departmento de Oceanografia, Universidad de Concepcion, Cabina 7 - Barrio Universitario, Casilla 160-C, \\ Concepcion 3, Chile \\ ${ }^{17}$ Department of Systems Ecology, Stockholm University, 10691 Stockholm, Sweden \\ ${ }^{18}$ Instituto de Ciencias del Mar y Limnologia, Universidad National Autonoma de Mexico, A. P. 70305 \\ Ciudad Universitaria 04510, Mexico \\ ${ }^{19}$ Ministry of Fisheries and Marine Resources, P.O. Box 912, Swakopmund, Namibia
}

Received: 4 September 2009 - Published in Biogeosciences Discuss.: 25 November 2009

Revised: 23 March 2010 - Accepted: 8 April 2010 - Published: 10 May 2010

\begin{abstract}
Hypoxia has become a world-wide phenomenon in the global coastal ocean and causes a deterioration of the structure and function of ecosystems. Based on the collective contributions of members of SCOR Working Group \#128, the present study provides an overview of the major aspects of coastal hypoxia in different biogeochemical provinces, including estuaries, coastal waters, upwelling areas, fjords and semi-enclosed basins, with various external forcings, ecosys-
\end{abstract}

Correspondence to: J. Zhang

(jzhang@ @sklec.ecnu.edu.cn) tem responses, feedbacks and potential impact on the sustainability of the fishery and economics. The obvious external forcings include freshwater runoff and other factors contributing to stratification, organic matter and nutrient loadings, as well as exchange between coastal and open ocean water masses. Their different interactions set up mechanisms that drive the system towards hypoxia. Coastal systems also vary in their relative susceptibility to hypoxia depending on their physical and geographic settings. It is understood that coastal hypoxia has a profound impact on the sustainability of ecosystems, which can be seen, for example, by the change in the food-web structure and system function; other

Published by Copernicus Publications on behalf of the European Geosciences Union. 
influences include compression and loss of habitat, as well as changes in organism life cycles and reproduction. In most cases, the ecosystem responds to the low dissolved oxygen in non-linear ways with pronounced feedbacks to other compartments of the Earth System, including those that affect human society. Our knowledge and previous experiences illustrate that there is a need to develop new observational tools and models to support integrated research of biogeochemical dynamics and ecosystem behavior that will improve confidence in remediation management strategies for coastal hypoxia.

\section{Introduction}

Coastal hypoxia, defined in this study as natural and/or anthropogenic dissolved oxygen (DO) depletion in coastal waters to a certain level (e.g. $<30 \%$ saturation or $<2 \mathrm{mg} / \mathrm{l}$ $=62.5 \mu \mathrm{M})$, has become recognized as a world-wide phenomenon since the late 1950s. It has caused a deterioration of a variety of characteristics important to the sustainability of marine ecosystems. The incidence and extent of coastal hypoxia has risen over the last century from $\sim 20$ sites before 1950 to $\geq 400$ sites at the beginning of this century, mainly as a result of increasing human derived discharges of nutrients and organic matter (Diaz and Rosenberg, 2008). Similarly, there is evidence for an increased incidence of hypoxia in shelf systems, mainly in areas subject to upwelling, that is potentially linked to regional climate adjustments of physical forcing factors (Grantham et al., 2004; Monteiro et al., 2006a; Bograd et al., 2008; Gilbert et al., 2005). Climate change can also influence the evolution of hypoxia/anoxia over decadal to geological time scales. However, because coastal hypoxia is closely associated with active feedbacks (e.g. emission of greenhouse gases) to the atmosphere, hypoxic systems also offer opportunities to study and understand the sensitivity of ecosystems to future high $\mathrm{CO}_{2}$ conditions (Naqvi et al., 2009; Santana-Casiano et al., 2009; Taguchi and Fujiwara, 2009).

The earliest systematic records of coastal hypoxia appear in literature from Europe and North America in 19101920. For example, episodic and/or seasonal hypoxic events were reported for 10 to 15 coastal water bodies in Europe (e.g. North Sea, Baltic Sea, Adriatic Sea, etc.) as well as for the east coast of the USA (e.g. Delaware, Long Island Sound and Chesapeake Bay) in the first twenty years of the 20th century; the reported negative effects on marine ecosystems included fish kills and mortality of benthic species (cf. Petersen, 1915; Sale and Skinner, 1917; Brongersma-Sanders, 1957; Andrews and Rickard, 1980; Mirza and Gray, 1981; Justic et al., 1987; Rosenberg et al., 1987; Patrick, 1988; Gerlach, 1990; Rosenberg, 1990; Parker and O'Reilly, 1991; D'Andrea et al., 1996; Arau'jo et al., 1999; Bricker et al., 1999; Fonselius and Valderrama, 2003). Since then there have been increasing reports of hypoxia from coastal regions world-wide, e.g. the Gulf of Mexico, Black Sea, and Baltic Sea (Rabalais and Gilbert, 2009, Oguz et al., 2000; Zaitsev and Mamaev, 1997), embayments, estuaries and fjords (e.g. Chesapeake Bay) (Kemp et al., 2005), and more recently off large rivers in East Asia (cf. Li et al., 2002). In view of the adverse effects of coastal hypoxia on marine life, the Scientific Committee on Oceanic Research (SCOR) constituted a Working Group (i.e. SCOR WG \#128) in the fall of 2005, whose Terms of Reference (TOR) were to:

1. Synthesize the state of the science for the following aspects of coastal hypoxia:

- prevalence and spatio-temporal variability,

- natural and human causes,

- effects on biogeochemistry and ecology, and

- resistance, resilience and recovery of ecosystems.

2. Identify gaps in our understanding of hypoxia and make recommendations for future research;

3. Determine the requirements for observing and modeling hypoxia and its impacts in coastal systems; and

4. Document the work of the group and generate synthetic publications that integrate results from the efforts listed above.

This special issue of Biogeosciences has been organized in accordance with these objectives. The synthesis in this special issue consists of 10 papers that deal with various aspects of natural as well as human induced hypoxia in coastal environments occurring on temporal scales ranging from episodic (i.e. irregular occurrence) to persistent (i.e. hypoxic events taking place over a time scale long enough to cause damage to the biota) and with spatial dimensions from tens to hundreds of thousands of square kilometers. This also includes retrieval of palaeo- and historical information on hypoxia from sediment cores.

\section{Understanding the causes of coastal hypoxia}

Dissolved oxygen concentrations in surface waters are governed by the balance between oxygen production (i.e. through photosynthesis), consumption (e.g. respiration and other chemical reactions that consume oxygen), and exchange with the atmosphere. The latter tends to maintain DO levels near saturation of dissolved oxygen for a given salinity and temperature (Fig. 1). In coastal environments, heterotrophic processes degrade organic matter using dissolved oxygen as an electron acceptor, either in the water column or in bottom sediments, or both; oxygen is also consumed during reoxidation of reduced constituents such as sulfide and methane (Fig. 1). In some coastal systems, ventilation 


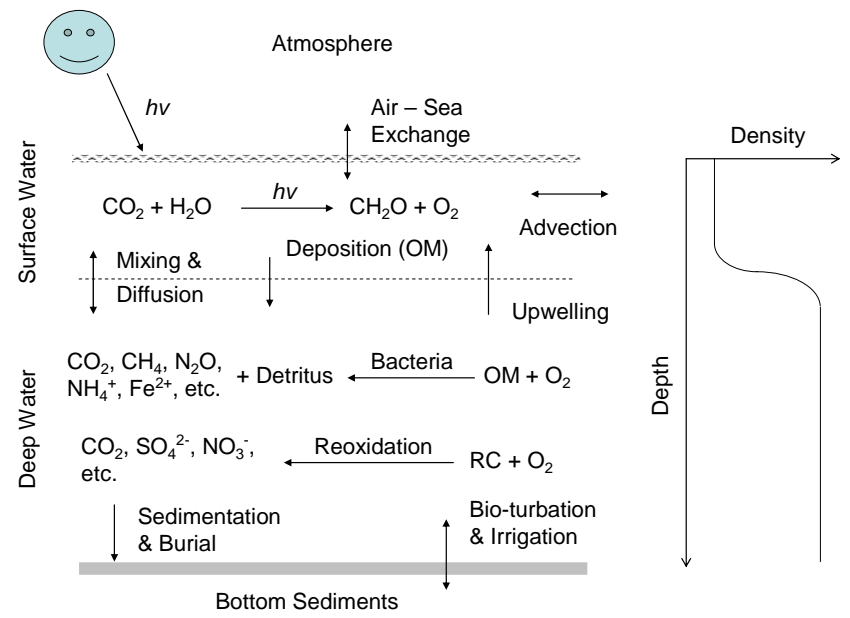

Fig. 1. Major mechanisms of production and consumption for dissolved oxygen (DO) in the coastal environment. In surface waters, high DO can be maintained by photosynthesis (hv is photon energy) and exchange with the atmosphere. Advection and turbulent mixing also affect the DO concentrations for a given water mass. In the deep part of the water column (e.g. beneath the pycnocline) and in bottom sediments, heterotrophic metabolisms (e.g. respiration), degradation of organic matter (OM), reoxidation of reduced constituents (RC) such as sulfide, methane etc., as well as chemoautotrophy (e.g. oxidation of ammonium) consume DO with a variety of pathways and, when the consumption exceeds DO supply, hypoxia develops.

is performed mainly through horizontal advection (Gilbert et al., 2005; Monteiro et al., 2006a; Bograd et al., 2008). Coastal upwelling can bring high concentrations of nutrients to surface waters and stimulate primary production and oxygen production. However, in certain coastal regions upwelled waters also bring low DO due to local or large scale (e.g. Eastern Tropical Pacific and Atlantic Basins) oxygen demand from microbial decay of sinking organic particles (Stramma et al., 2008).

The numerous physical and biogeochemical processes regulating DO concentrations make it challenging to understand coastal hypoxia based on observations alone. Biogeochemical models that include the oxygen cycle have contributed to improved understanding of diverse aspects of hypoxia such as for example, processes responsible for the development of hypoxia, controls on extent and temporal variability, its impacts on biogeochemical cycles, and predictions of climate change responses (Peña et al., 2010). Moreover, recent advances in 3-dimensional coupled physical-chemicalbiological models have contributed to the improved quantitative understanding of the physical and biological processes leading to hypoxia (e.g. Gregoire and Lacroix, 2001).

The results of individual coastal hypoxia studies have substantially increased our understanding of biogeochemical processes and ecological consequences that can be related to the dynamics of hypoxia across the world coastal ocean.
These findings demonstrate the critical role of biogeochemistry and its interaction with physical ventilation, by advection in shelf systems and vertical mixing in shallow inshore systems, in understanding the evolution of coastal hypoxia in many different physical and geographic settings (Gilbert et al., 2005; Monteiro et al., 2006a).

In shallow systems (i.e. water depth is typically $<50 \mathrm{~m}$ ), concentrations of DO in the water column can also be modified by turbulent mixing and biogeochemical consumption and production. For instance, hypoxia near the mouths of large rivers and in estuaries tends to have a seasonal character that is related to the input of freshwater, terrestrial nutrients and the nature of circulation, and hypoxia itself may have an inverse relation to the stability of the water column. Enhanced vertical stratification and restricted horizontal exchange with the open ocean (i.e. long residence time) may support the persistence of hypoxia and even the development of anoxia (Rabalais and Gilbert, 2009) in bottom waters. More specifically, coastal hypoxia off the large rivers of the world responds to the steady increase of nutrients from catchment areas. In the case of the Northern Gulf of Mexico, the load of dissolved nitrogen from the Mississippi River seems most important (Justic et al., 2003), which emphasizes that eutrophication and hypoxia can be related through the complex mechanisms driving cycling of nutrients and microbial processes in coastal environments. There are comparable examples in the discharges of the Changjiang (Yangtze River) into the East China Sea (Li et al., 2002).

Detailed information about similarities and differences among hypoxic sites in the global coastal ocean gives insights into the complex cross-links with climate change and human perturbations on ecosystems both in land and marine sectors. Comparative studies also clarify how biogeochemical dynamics defines the magnitude and consequences of coastal hypoxia. High-resolution measurements have enabled the establishment of cross-boundary and mechanistic understanding of the emergent, evolving and declining phases of coastal hypoxia (Kemp et al., 2009). The episodic, periodic (i.e. hypoxic events occurring with a regular character in time) and/or persistent nature of coastal hypoxia allows an estimate of the time lag between the accumulation of organic matter in the water column, microbial consumption of dissolved oxygen and subsequent mineralization processes.

The approach of SCOR WG \#128 has been to provide a platform to examine bottom-up (i.e. physical and biogeochemical processes) control on food-web structure and function in the coastal marine environment. For instance, stocks and diversity of benthic macrofauna and megafauna decrease in the regions affected by hypoxia, but a high biomass can be found at the edges of low DO areas or at the boundary between oxygen depleted and replete waters, while meiofauna may not show any change (Levin et al., 2009). Thus, unlike the situation in normoxic environments, changes in oxygenation affect the entire ecosystem (i.e. including benthic foodwebs and the pelagic system), permitting an understanding 
of the DO history over the past decades to millennia through analysis of various faunal, chemical and mineral proxies in sediment strata (Gooday et al., 2009). This enables assessment of the interplay of biogeochemical cycles and ecosystem functions, such as hypoxia-induced shifts in nitrogen cycling pathways (e.g. denitrification) and the associated feedbacks to the overlying water column via nitrogen recycling (Kemp et al., 2005) and atmosphere, e.g. $\mathrm{CH}_{4}$ and $\mathrm{N}_{2} \mathrm{O}$ emission (Naqvi et al., 2000).

The biogeography and/or the biogeochemical provinces of coastal hypoxia, together with the model constructions of trophic dynamics, enable a comparison to be made of ecosystem functioning in low-oxygen settings across the world ocean. Such syntheses are required for linking present ocean processes to paleo-oceanographic records and for predicting future ecosystem states. Together, the world-wide occurrence and spreading of coastal hypoxia create an imperative for improved biogeochemical models and understanding of linkages among ecosystem processes, which in turn will guide the development of new models and observational tools. It is expected that coupling of pelagic and benthic biogeochemical dynamics and ecosystem responses, and interaction with the atmosphere incorporated in coupled Earth Systems Models will be cross-linked in the next generation of models (Soetaert and Middelburg, 2009). Such an approach requires an increase in spatial and temporal resolution of observations and improvement in numerical techniques as well. This advance will provide a better understanding of how the complex interplay of physical, biogeochemical and ecological processes affect the temporal evolution of ecosystem functioning in various bio-geographic provinces and within the context of changing climate.

The cumulative number of reported hypoxic systems in the literature has risen exponentially over time, with a dramatic increase since the 1980s (Diaz and Rosenberg, 2008). Before 1980 , over half $(52 \%)$ of the records of hypoxia originated from Europe, more than 4 times the number in Asia (10\%, mostly from Japan). Since the 1980s, the number of hypoxic sites in North America (43\%, mostly from the United States) has become greater than in Europe (39\%), as shown in Fig. 2a. Moreover, before 1980, episodic events accounted for $13 \%$ of the total number of hypoxic systems, while periodic and seasonal hypoxic systems accounted for $66 \%$, followed by persistent hypoxic events at $19 \%$ (Fig. 2b). After the 1980s, there has been a reduction relative to the pre-1980s for episodic (11\%), periodic and seasonal (55\%) and persistent $(3-4 \%)$ hypoxia, while the proportion of hypoxic events for which the frequency of occurrence remains unknown has increased (Fig. 2b). About 30\% of hypoxic systems reported in the literature after 1980 have causal mechanisms that remain unknown (Fig. 2b). By comparing oxygen concentration trends from the 1951-1975 period with the 1976-2000 period, Gilbert et al. (2009) showed that the proportion of negative trends was significantly higher in 1976-2000, indicating a degradation of oxygen conditions in recent years.
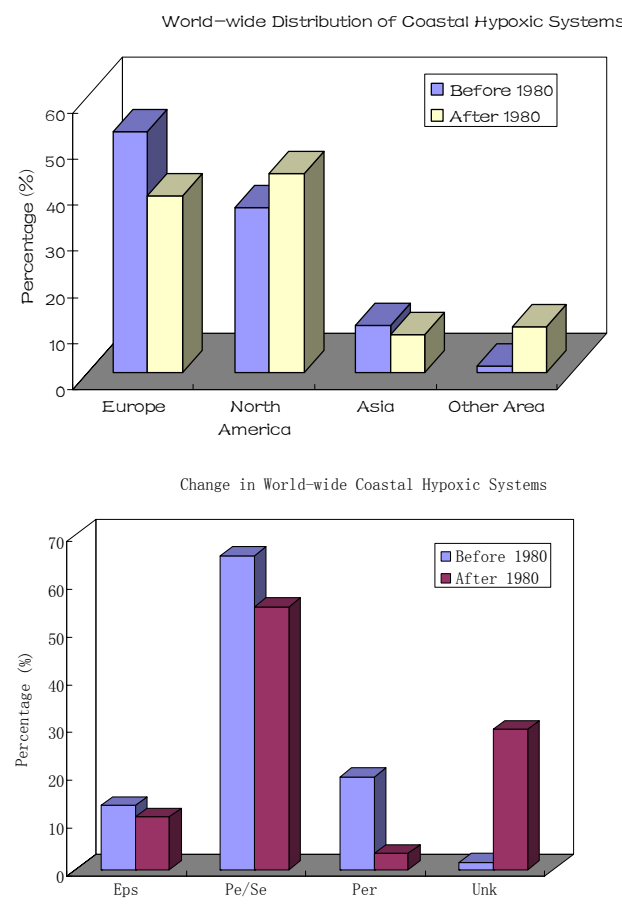

Fig. 2. Comparison of world-wide distribution of hypoxic systems before and after 1980, with (a) hypoxic systems per geographic category, and (b) classification according to type of hypoxia: Eps episodic, Pe/Se - periodic and seasonal, Per - persistent, and Unk - for which the hypoxia behavior is not well recognized (i.e. unknown). Data are from Diaz and Rosenberg, 2008.

\section{Hypoxia in coastal upwelling systems}

Natural hypoxia has long been known to occur in most coastal upwelling systems, e.g. off Benguela (Copenhagen, 1953; Chapman and Shannon, 1985), western India (Banse, 1959; Carruthers et al., 1959) and Peru (Dugdale et al., 1977). However, the number of reports of hypoxia and ecosystem impacts from such systems has increased since the 1980s (Diaz and Rosenberg, 2008). Tropical and subtropical eastern boundary upwelling systems have a complex interaction with oceanic boundary currents owing to the combination of the Coriolis effect and wind-forcing in the sub-tropics as well as tropical planetary Rossby and Kelvin waves (Dewitte et al., 2008; Lass and Mohrholz, 2008). Nutrient enrichment of the euphotic zone caused by upwelling makes these systems highly productive, which in turn leads to high oxygen consumption rates in subthermocline waters. Oceanic Oxygen Minimum Zones (OMZs) form in the shadow of the subtropical gyral circulation, where sub-thermocline waters are less vigorously ventilated (Lass and Mohrholz, 2008; Karstensen et al., 2008). Cross-shore exchanges of water mass properties through extra-tropical Rossby waves or mesoscale eddies between the ventilated coastal region and the open ocean may provide a mechanism for maintaining extended oxygen minimum zones in these 
eastern boundary current systems (Bonhomme et al., 2007). This results in the formation of extensive oxygen minimum zones in the mesopelagic realm, particularly in the Humboldt (i.e. Peru-Chile) Current and California Current systems in the eastern Pacific Ocean (Deuser, 1975; Helly and Levin, 2002; Paulmier and Ruiz-Pino, 2008). In the Indian Ocean, the most vigorous upwelling occurs in the north (i.e. in the Arabian Sea) and not along its eastern boundary (e.g. off Western Australia), where upwelling is suppressed by the pole-ward Leewin current. The OMZs of the Indian Ocean is therefore found in its northern basins (i.e. Arabian Sea and Bay of Bengal). In the Atlantic Ocean, severe oxygen depletion is restricted to the Benguela system off Namibia, while the Canary Current System (i.e. off Mauritania-Morocco) is not known to support large scale hypoxia. Upwelling of oxygen-depleted southern hemisphere thermocline water in these regions is the primary cause of the development of hypoxic conditions in shelf waters (Monteiro et al., 2008).

Where upwelling is more or less perennial (e.g. off Peru), hypoxic conditions may persist throughout the year. More often, upwelling intensity varies seasonally, resulting in marked seasonal changes in coastal hypoxia, e.g. off southern Chile, Benguela (i.e. Namibia and South Africa) and western India. Thus, in all these and other similar systems, physical processes play a key role in controlling the vertical structure of hydrographic parameters and the supply of water masses with low DO (Grantham et al., 2004; Monteiro et al., 2006, 2008; Bograd et al., 2008). The uniqueness of the eastern boundary upwelling system is their connection with equatorial variability (Pizarro et al., 2002; Rouault et al., 2007), which allows for a remote control of hypoxia events through the pole-ward propagation of equatorial Kelvin waves that may act on the oxycline along the coast (Monteiro et al., 2006a, 2008; Guttierez et al., 2008). In the Humboldt system, along-shore wind variability associated with the South Pacific Anticyclone activity also induced Ekman pumping and transport off central Peru and central Chile (Renault et al., 2009) that may favor the occurrence of hypoxia events. Compared to other coastal hypoxic areas, oxygen depletion in upwelling systems may occur in sub-surface waters, mostly due to the presence of a pole-ward undercurrent lying on the continental slope that carries poorly oxygenated waters from the equatorial OMZs (Monteiro et al., 2006a, 2008; Mohrholz et al., 2007; Guiterrez et al., 2008). On the shallow continental shelves, hypoxia events induced by upwelling can cause mass mortality of benthic fauna and diminish ecosystem services (Carruthers et al, 1959; Cockroft, 2001; Grantham et al., 2004). The large scale characteristics of the oxygen minimum layer and shelf hypoxia have a direct impact on fisheries by changing boundary conditions for spawning and early life history of economically important species (Ekau et al., 2009).

Hypoxia may result in the occurrence of denitrification in the water column (Naqvi et al., 2000 and 2009). It has been suggested that, in addition to denitrification, anaerobic am- monium oxidation (e.g. anammox) is an alternative mechanism regulating nitrogen cycling in the bottom waters of coastal upwelling systems (Kuypers et al., 2005). Complete consumption of nitrate triggers the onset of sulphate reduction (Dugdale et al., 1977; Naqvi et al., 2000 and 2006). Upwelling induced hypoxia may also cause massive release of hydrogen sulfide and methane from the sediments as happens in the Namibian coastal system (Weeks et al., 2002; Lavik et al., 2009). Sediment underlying hypoxic upwelling systems often support microbial communities comprising large, nitrate-storing bacteria because of high bottom-water nitrate concentrations (Schulz and Jørgensen, 2001). Upwelling systems with hypoxic or anoxic waters can also be significant $\mathrm{CO}_{2}$ sources to the atmosphere in contrast to comparable aerated systems which are typically $\mathrm{CO}_{2}$ sinks (SantanaCasiano et al., 2009).

Like other coastal areas, upwelling systems have been impacted by human activities such as eutrophication to varying degrees. For example, the world's largest natural hypoxic zone that develops seasonally over the Western Indian continental shelf appears to have intensified over the last three decades (Naqvi et al., 2000 and 2009). Given the huge increase in fertilizer consumptions in South Asia, this region is expected to receive large amounts of anthropogenic nutrient loadings through land runoff and atmospheric deposition (Seitzinger et al., 2002; Duce et al., 2008). Thus, the combination of upwelling and eutrophication is probably the major cause of the observed increase in hypoxia. However, variability of hydrography and circulation as an alternative or additional causative mechanism cannot be ruled out. Such changes have been invoked to explain the intensification of hypoxia in the California Current System in the last few years (Grantham et al., 2004; Bograd et al., 2008). However, the relative importance of eutrophication and physical changes, as well as human-induced effects and natural variability in driving hypoxia variability in various upwelling systems are still not fully established. In the Changjiang Estuary and East China Sea Shelf, the ratio between different nutrient species [e.g. $\mathrm{NH}_{4}^{+}$vs. $\mathrm{NO}_{3}^{-}$and organic vs inorganic phosphorus (i.e. DOP vs DIP)] has been used to disentangle the effect of nutrients related to coastal eutrophication versus physical effects. The levels of $\mathrm{NO}_{3}^{-} / \mathrm{NH}_{4}^{+}$and DIP/DOP over the broad shelf of East China Sea indicate the replenishment of nutrients upwelled through the incursion of Kurosio Current across shelf-break, whereas in the eutrophic waters closer to the coast, ratios between oxidized and reduced forms as well as inorganic to organic forms of nitrogen and phosphorus become much lower (Zhang et al., 2007).

Eastern Boundary Current systems of the southern Hemisphere may be very sensitive to climate change due to their connection with equatorial variability and to change in land-sea thermal contrast associated with a warmer atmosphere and driving upwelling-favorable coastal winds. This is likely to translate into changes in hypoxia event statistics (i.e. occurrence and magnitude) in these regions. Moreover, 
climate models and recent observational studies predict expansion of the eastern boundary oxygen minimum zones under global warming conditions (Matear and Hirst, 2003; Stramma et al., 2009).

\section{Hypoxia off river mouths and in estuaries}

Hypoxia in the Adriatic Sea off the River Po was among the first cases attributed to human activities (Justic et al., 1987). Hypoxia that develops in coastal areas off the river mouths, notably the Mississippi River, Changjiang (Yangtze River), Pearl River (Zhujiang), Danube River, and Susquehanna River (Zaitsev, 1992; Turner and Rabalais, 1994; Li et al., 2002; Rabalais et al., 2002; Yin et al., 2004; Hagy et al., 2004; Black Sea Commission, 2008), usually has been related to anthropogenic activities in the catchment areas on land. In particular, changes in land-use and agriculture (e.g. application and substantial loss of chemical fertilizers), combustion of fossil fuel, and release of municipal and animal wastes to the aquatic environment have resulted in large increases in nutrients (i.e. mostly nitrogen and phosphorus) loads of rivers world-wide. Several models have been developed to understand the mechanisms that link river discharge and nutrient concentration to hypoxia development and cessation (Peña et al., 2010). These models have been useful for planning and forecasting possible responses of marine ecosystems to different management scenarios and for providing guidelines in setting goals of nutrient reduction. It is estimated that riverine nutrient fluxes to the world ocean have increased by a factor of two to four in the 20th Century relative to the pre-industrial period. The increase in nitrogen load may have been even higher for some regions, 5- to 10fold in Europe and North America (Boesch, 2002; Howarth et al., 2002) (Fig. 3). The number of coastal hypoxic systems and the amount of industrially fixed nitrogen has increased rapidly since the 1960s, with both trends showing a similar pattern (Fig. 3). However, a closer examination of the data indicated that such a rapid increase of industrial nitrogen, mainly of chemical fertilizers, is largely responsible for the increasing numbers of coastal hypoxic sites, but with a delay of ca. 5-10 years (Diaz, 2009).

It should be remembered that cumulative numbers of reported hypoxic events may not be a true measure of the hypoxia problem, like other deteriorations in coastal environments (e.g. Harmful Algal Blooms). Although there is a correlation between nutrient export from watersheds (e.g. fixed nitrogen) and coastal hypoxia that can be inferred from publications in literature, this could be because hypoxia has become a topic that is more interesting to scientific and public societies today than fifty years ago. Locally, there are many types of human activities that can be related to the evolution of coastal hypoxia, like change in land-sources input (e.g. freshwater, sediment, nutrients and other pollutants), coastal engineering (e.g. dredging for navigation and recla-

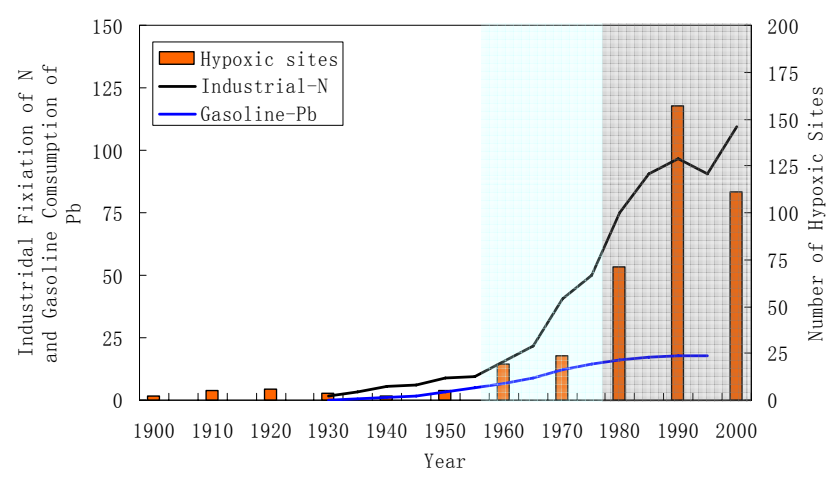

Fig. 3. Temporal relationship between the number of coastal hypoxic sites (Hypoxic sites: events/decade), accumulative industrial fixed nitrogen (Industrial-N: $\times 10^{6}$ tons), and alkyl $\mathrm{Pb}$ consumption (Gasoline- $\mathrm{Pb}: \times 10^{5}$ tons) in US and major European countries (i.e. France, Germany, Italy and UK, altogether accounting for $70 \%$ of EU gasoline consumption). Gasoline-Pb is another indicator of anthropogenic perturbations on marine environment but mostly through the atmospheric pathway. The leveling-off of alkyl $\mathrm{Pb}$ consumption took place in the 1970s-1980s because of bans against lead use in gasoline, and since then $\mathrm{Pb}$ level in ocean surface waters has decreased. Industrial fixed nitrogen, mainly used for fertilizer application, shows a fast increase in the 1960s-1970s and a slow-down after the 1980s; the number of coastal hypoxic sites per decade dramatically increased after the 1960s and reached a peak in the 1990s. It is believed that 1960-1980 was a period of explosive increase of coastal eutrophication (i.e. light green shadowed area). However, in developing and economically emerging countries, coastal eutrophication and hypoxia has become more serious in the period of 1980-2000 (i.e. grey shadowed area) (modified from Boyle, 2001; Boesch, 2002; Diaz and Rosenberg, 2008).

mation) and marine aquaculture that have increased over the time span indicated in Figs. 2 and 3 and can be linked to individual hypoxic systems. On a regional and global scale, however, nutrient enrichment owing to nitrogen fixation and nutrient loss from watersheds is believed to be the major anthropogenic forcing for the reported hypoxia in coastal environment (Rabalais et al., 2009, 2010).

Coastal eutrophication often occurs in waters receiving river discharge, when nutrient over-loading results in increased productivity that provides abundant organic matter for microbial degradation (Fig. 1). Organic matter photosynthesized under eutrophic conditions is labile and can be readily degraded, while that derived from soils and terrestrial vegetation tends to be much more refractory because of degradation during transport from land to the sea (Wu et al., 2007). Inputs of freshwater through river runoff also enhance stratification in adjacent marine water bodies, which reduces vertical mixing intensity and oxygen penetration into subsurface waters and promotes low-oxygen waters near the sea floor. Hypoxia in estuaries and coastal bays may also be fueled by labile organic matter inputs from adjacent watersheds or upwelling systems. Low oxygen in the deeper part of 
the water column can also arise from incursion of offshore oceanic waters naturally low in dissolved oxygen. Examples include the influence of the Western Boundary Current in the NW Pacific Ocean, the Kuroshio on the East China Sea Shelf, particularly the area offshore the Changjiang; the sub-surface waters of the Kuroshio have relatively low dissolved oxygen (ca. 125-150 $\mu \mathrm{M}$ ) (cf. Li et al., 2002; Zhang et al., 2007). Mesoscale intrusions of subsurface suboxic waters from the Rim Current of the Black Sea general circulation system also episodically modulate the near-bottom oxygen structure of northwestern shelf (Black Sea Commission, 2008). Longterm observations show that coastal hypoxia off large river mouths and in estuaries/bays has an important seasonal (Rabalais et al., 2001) and/or inter-annual component (Gilbert et al., 2005; Kemp et al., 2009) that can be related to climate variability as well. For example, the annual discharge of the Mississippi River is predicted to increase by $20 \%$ if the concentration of atmospheric $\mathrm{CO}_{2}$ doubles, and nutrient load would increase as well, which will induce stronger stratification and more serious eutrophication, followed by an ever intensified hypoxia on the Louisiana Continental Shelf (Rabalais and Gilbert, 2009).

Diaz and Rosenberg (2008) found 60-70 hypoxia records in the literature prior to 1980 , of which $18 \%$ were reported from river/estuary systems; since 1980 another 330-340 cumulative hypoxia reports have been published, of which the proportion from hypoxic river-estuary systems increased up to $22 \%$. The actual number of hypoxic systems that can be related to land-source inputs exceeds $20-25 \%$ of recorded sites in the literature, because the ecosystem functioning of some lagoons and bays are also influenced by freshwater influx into the system.

\section{Hypoxia in semi-enclosed seas and basins}

Marine basins that are semi-enclosed by land-mass may have a signature of oxygen depletion in deep and bottom waters, but that sometimes extends very close to the surface. This oxygen depletion can be seasonal or perennial, as in the Black Sea, Cariaco Basin, Baltic Sea, Kau Bay, Santa Barbara Basin and many other similar fjord-type environments (Oguz et al., 2000; Rabalais and Gilbert, 2009). Oceanographic processes that regulate hypoxia in semi-enclosed marine settings include restricted exchange with the open ocean and prolonged residence times of subsurface waters in the basins. Physical controls are also important for water column stratification, which isolates oxygen depleted deep water from the well oxygenated surface layer and allows low oxygen conditions to fully develop in the deeper water column. Surface phytoplankton blooms that are usually induced by land-source or upwelling-derived input of new nutrients, sustain an enhanced vertical flux of organic matter to deep waters. In these semi-enclosed, hypoxic systems, the ratio of recycled to new production can be higher than in open water settings.

Semi-enclosed basins with a shallow sill at the entrance are very susceptible to hypoxia and can be found at highlatitudes (e.g. fjords in Norway, Sweden and Canada), in the temperate zone (e.g. Black Sea, which contains the world's largest body of permanently anoxic water) as well as in the tropics (e.g. Cariaco Basin and Kau Bay). Stratification can be pronounced in the case of strong vertical gradients in salinity and temperature in higher-latitude systems (e.g. Baltic Sea) or more subtle in the case of tropical basins. Water renewal in these hypoxic, silled basins depends on regional processes (i.e. wind, freshwater run-off and ground water discharge) and the density of seawater just outside the silled basin. Water renewal in silled basins may be controlled by global or distant mechanisms such as El Niño (e.g. Kau Bay) or the North Atlantic Oscillation (e.g. Baltic Sea) (Hanninen et al., 2000; Gooday et al., 2009). Advection of North Sea water into the Baltic Sea anoxic basins results in a cascade of biogeochemical reactions with major consequences for food web structure and ecosystem functioning. Similar processes have been reported for intrusion of Mediterranean waters via the Bosporus into the upper part of anoxic Black Sea water column (Glazer et al., 2006). These natural and climate-change sensitive bottom water renewal events cause interruption of hypoxia/anoxia and the consequences are reflected in the sedimentary records (Kennett and Ingram, 1995; Gooday et al., 2009). These semi-enclosed hypoxic basins therefore amplify subtle global change effects into easily detectable and more pronounced changes in ecosystem properties and therefore represent natural laboratories.

\section{Coastal hypoxia and benthic biota}

Benthic ecosystems experience changes in levels of dissolved oxygen on variable time and spatial scales and in numerous stages of the physiology, reproductive cycle, and auto-ecology of organisms. When dissolved oxygen becomes depleted in the lower part of the water column, benthic organisms exhibit stressed behaviors, and ultimately mortality and changes in community structure will result. Besides oxygen stress, the formation of hydrogen sulfide in bottom waters normally results in the death of most metazoans, although some taxa are physiologically adapted. Mobile nekton will avoid an area when oxygen concentrations are too low; sessile invertebrates in near bottom waters may undergo mass mortality and burrowing organisms escape from their burrows and lie motionless on the bottom. However, species-specific thresholds are not well known, vary with body size and taxon, and thus no single definition of hypoxia fits the physiological and behavior responses of all exposed organisms (Vaquer-Sunyer and Duarte, 2008; Levin et al., 2009). The results of coastal water hypoxia on physiological responses and survival for benthic organisms can be very 
complex, depending on the structure of food webs and life histories of affected species. Larval stages are often more sensitive than adult individuals to low oxygen concentrations and hence less tolerant to hypoxia. The severity of the impact of hypoxia on coastal benthic systems is determined not only by the level of dissolved oxygen but also the temporal scale of exposure (Rabalais et al., 2010).

Permanent hypoxia can have a profound impact on the species composition and biodiversity at a community level, relative to areas affected by episodic and/or periodic hypoxic events that cause damage, mostly at the species level (e.g. life history). Hypoxic areas show a trend of lower biomass/abundance of large-size organisms, a skew towards small-sized organisms, and a loss of deep-dwelling and longlived species. A reduction of species diversity is usually accompanied by dominance of one or a few oxygen tolerant species (Levin, 2003). Benthic communities in areas of permanent or high frequency of hypoxia/anoxia, e.g. oxygen minimum zones that impinge on sea mounts or continental margins routinely exposed to hypoxia through enhanced production in upwelling systems, differ from those in areas more recently exposed to hypoxia, periodic or seasonally persistent, over the last ten decades. Evolutionary selection and adaptive mechanisms have shaped the former over many millennia, while those more recently exposed to human-caused hypoxia are not tolerant to continued low dissolved oxygen conditions (Levin et al., 2009). In ecosystems experiencing hypoxia, habitat is also compressed and/or even lost. In terms of mortality, echinoderms and crustaceans (e.g. shrimp and crabs) are typically most vulnerable, followed by mollusks, with polychaetes often the most resistant metazoan macrofaunal taxon to low oxygen levels (Jørgensen, 1980, 1982; Díaz and Rosenberg, 1995).

In regions subject to episodic and/or periodic hypoxia, the damaged benthic ecosystem may not necessarily recover immediately after the return of normal oxygen conditions. In both natural and anthropogenically caused hypoxia there is enhanced deposition of labile organic matter (e.g. phytoplankton detritus, fecal pellets, and marine aggregates) that can cause the bottom sediments to become more heterotrophic with an increase in oxygen demand and hence an increase in re-mineralization of nutrients and certain trace elements (Middelburg and Levin, 2009). However, it is hard to distinguish whether low DO induces higher preservation of organic matter (i.e. retardation of decomposition of organic materials by heterotrophic bacteria owing to hypoxia) or if higher organic matter in bottom sediments causes a reduction of dissolved oxygen (i.e. an increase in organic-matter flux fuels heterotrophic degradation that consumes oxygen).

Hypoxia has a significant effect on benthic animals with the consequences that ecosystem functions related to macrofauna such as bio-irrigation and bioturbation are significantly affected by hypoxia. Since many microbes and microbial-mediated biogeochemical processes depend on animal-induced transport processes (e.g. re-oxidation of par- ticulate reduced sulfur and denitrification), there are indirect hypoxia effects on biogeochemistry via the benthos. The consequences of hypoxia-induced macrofaunal diversity loss on biogeochemistry are multiple, complex and not well identified, and can be linear or non-linear, depending on the community composition of the remaining infaunal organisms (cf. Middelburg and Levin, 2009), and of course, are much more easily studied on an individual basis or in a singlespecies population than a complex benthic community.

Bio-irrigation results in the enhanced transport of oxygen into the sediments and consequently enhanced rates of aerobic respiration up to a point when dissolved oxygen concentrations become limiting. It also causes enhanced exchange of nutrients and other metabolites dependent on the autoecology, density, and depth distribution of animals (Aller, 2001). For instance, bioirrigation may stimulate nitrification by supply of oxygen, but may also stimulate effluxes of ammonium and nitrate with the result that the net effect on nitrogen cycling (i.e. nitrification, denitrification and anammox) depends in a complex way on bio-irrigation (Aller, 2001). Bioirrigation also stimulates patchiness in geochemical conditions and thus can act to maintain faunal biodiversity within the sediment by creating a mosaic of biogeochemical habitats and rate processes (Waldbusser et al., 2004).

Bioturbation, the enhanced dispersal of particles resulting from sediment reworking by burrowing animals, is due to tube construction, burrowing, feeding and relocation of animals (Meysman et al., 2005, 2008). Particle displacement has many consequences for sediment biogeochemistry: e.g. labile organic matter is transported downward and diluted into a larger pool of refractory carbon and metal oxides delivered to or formed in the surface sediments may be transported downward to more reduced layers (Burdige, 2006). Conversely, reduced products such as iron sulfide (i.e. pyrite) may be mixed from subsurface to surface layers where they are then oxidized by oxygen, nitrate or other oxidants (Meysman et al., 2006). These shifts in biogeochemical processes significantly alter the balance of oxidized and reduced species of nutrients and elements.

Hypoxia directly and indirectly (e.g. via benthos) impacts benthic microbiota and biogeochemistry. Low DO in the bottom water directly influences respiration pathways (i.e. anaerobic processes increase at expense of aerobic respiration) and sediment-water exchange fluxes. Reduced components such as iron (II), manganese (II), ammonium and hydrogen sulfide are efficiently recycled within sediments if oxygen is available for re-oxidation of the reduced forms and consequently less can escape to the overlying waters (Middelburg and Levin, 2009). Low DO may thus result in enhanced release of ammonium and phosphate, because its recycling is intimately linked to that of iron (Conley et al., 2009a). This enhanced release of nutrients may in turn stimulate organic matter production (Kemp et al., 2005, 2009).

Indirect effects of oxygen on sediment biogeochemistry occur via the effect of hypoxia on benthic animals (Levin et 
al., 2009). Hypoxia affects the functioning of benthic animals such that bio-irrigation and bioturbation activities decline and eventually are eliminated, when benthic animals have disappeared, with major consequences for sediment biogeochemistry and sediment-water exchange rates (Middelburg and Levin, 2009).

Generally, for a given organic carbon loading more organic carbon is directed towards microbes at the expense of higher organisms when oxygen levels decline (Diaz and Rosenberg, 2008). Long periods of hypoxia may induce complete elimination of fauna from sediments and result in the accumulation of organic matter and large stocks of iron sulfide. Restoration of bottom-water oxygen conditions may then not directly lead to full recovery of sediment ecosystem functioning because re-establishment of fauna may involve successions (Diaz and Rosenberg, 2008) and because accumulated sedimentary organic matter and sulfides may attenuate recovery processes (Soetaert and Middelburg, 2009; Middelburg and Levin, 2009). This may lead to hysteresis in the system response (Kemp et al., 2009 and Sect. 12, Fig. 6).

Hypoxia affects the functioning of benthic communities by reducing the diversity of lifestyles and species, favoring animals that live and feed near the sediment-water interface. This acts to reduce the amount of bio-irrigation and bioturbation and eventually eliminates these functions when benthic animals have disappeared, with major consequences for sediment biogeochemistry and sediment-water exchange rates (Middelburg and Levin, 2009).

\section{Sediment records of coastal hypoxia}

Ultimately, biogeochemical dynamics in marine sediments are intimately linked to the condition of the water column. The re-mineralization of nutrients and trace elements in the upper sediment layers and at the sediment-water interface are fueled by the depositional flux of organic materials through the water column, while the oxygen supply in benthic systems can be through turbulent mixing, diffusion and bioirrigation (Fig. 1). In hypoxic environments, anaerobic respiration results in formation of various reduced substances, such as $\mathrm{N}_{2}$ and $\mathrm{NH}_{4}^{+}, \mathrm{N}_{2} \mathrm{O}, \mathrm{Fe}$ (II), Mn (II), $\mathrm{H}_{2} \mathrm{~S}$, intermediate oxidation state sulfur species like thiosulfate, sulfite and elemental sulfur, and metal sulfur complexes and $\mathrm{CH}_{4}$. These products occur along with a redox cascade in the use of oxidants, which can be efficiently re-oxidized within benthic ecosystems because they contain a substantial amount of energy transferred from the original organic matter (Middelburg and Levin, 2009). In the hypoxic coastal environment, anaerobic processes dominate biogeochemical cycling, because high carbon loading creates a large oxygen demand (e.g. heterotrophic degradation) that is not balanced by oxygen supply from either the upper part of the water column or exchange with other water bodies with higher oxygen content. In fact, oxygen consumption by re-oxidation pro- cesses can be three times higher than the amount of consumption from aerobic respiration (Glud, 2008). The more complex chemical reduction chains in low oxygen conditions (e.g. hypoxia) further stimulate trace elements (e.g. Fe and $\mathrm{Mn}$ ) and nutrients (e.g. $\mathrm{N}$ and $\mathrm{P}$ ) recycling, and hence affects the function of benthic communities relative to the situation under aerobic respirations (Middelburg and Levin, 2009). The combined effect of anaerobic reduction and heterotrophic metabolism in hypoxic conditions can retard recovery of oxygen deplete conditions (Kemp et al., 2009).

In hypoxic settings, heterotrophic denitrification is favored relative to nitrification, but the rate of denitrification is regulated by the level of nitrate in near-bottom waters; an increase in nitrate concentration can dramatically promote denitrification (Middelburg and Levin, 2009). As the oxygen level in near-bottom waters decreases, Fe and Mn oxides and/or hydroxides are reduced to soluble Fe (II) and Mn (II) along with heterotrophic degradation of organic materials. Thermodynamic control means that Mn-oxides are usually utilized at higher redox conditions than Fe-oxides. Soluble Fe (II) can then combine with sulfur to form insoluble sulfides, if the system becomes anoxic. When heterotrophic respiration and degradation of organic materials consume dissolved oxygen in the water column, the $\mathrm{pH}$ also decreases. The $\mathrm{pH}$ can be as low as 7.5-7.6 in hypoxic waters compared to surface seawaters that typically have $\mathrm{pH}$ values around 8.1 , and much lower in pore waters, lowering carbonate saturations states and potentially negatively affecting species with carbonate skeletons or shells (Green and Aller, 2001). Hence, besides the direct impact of hypoxia on the ecosystem by reducing dissolved oxygen in near-bottom waters, benthic species can suffer from aggravated carbonate dissolution associated with reduced $\mathrm{pH}$ (i.e. corrosive water body).

The evolution of hypoxia in the coastal ocean can be inferred from microfossils, biomarkers and the chemical and mineralogical composition of bottom sediments. However, accurate quantitative proxies for palaeo-oxygenation remain elusive and distinguishing the effects of hypoxia from those of eutrophication without DO-depletion poses a considerable challenge. Foraminifera are by far the most widelyused benthic faunal indicators for hypoxia in near-bottom waters. Some species have the physiological ability to withstand severe hypoxia or even temporary but not long-term anoxia. For example, infaunal calcareous species with thinwalled tests and flattened, elongate biserial/triserial, planispiral/lenticular or globular test morphologies, are common in hypoxic environments (Bernhard and Sen Gupta, 1999; Jorissen, 1999), although they also occur in organically-enriched sediments overlain by oxic bottom water (Jorrisen et al., 1998). Depressed species richness and diversity is another indicator of oxygen depletion (Gooday, 2003; Gooday et al., 2009). Ostracods are generally intolerant of hypoxia, and like foraminifera, species richness is depressed in oxygenstressed situations. In hypoxic settings, benthic assemblages are characterized by the dominance of a few exceptional 
species. Other bottom-sediment parameters that have been used to track the evolution of coastal hypoxia include sediment texture and other properties (e.g. development of laminations and color), the chemical and mineral composition (e.g. pigments, sulfides and trace metals), and the presence of authigenic minerals (e.g. glauconite) (Gooday et al., 2009). The occurrence and evolution of hypoxia can also be inferred from the sedimentary records of planktonic organisms (i.e. diatoms and dinoflagellate cysts, indicators of high levels of primary production linked to eutrophication) and the composition of organic matter and associated stable isotopes ratios (i.e. $\delta^{13} \mathrm{C}$ and $\delta^{15} \mathrm{~N}$ ). Since $\mathrm{CO}_{2}$ is used in photosynthesis, an increase in $\mathrm{CO}_{2}$ in a hypoxic water column due to enhanced respiration may result in lighter $\delta^{13} \mathrm{C}$ values for synthesized organic matter. Photosynthesis using regenerated nitrogen (e.g. $\mathrm{NH}_{4}^{+}$produced in hypoxic conditions as product of ammonification) can induce a higher $\delta^{15} \mathrm{~N}$ value (e.g. 5-10\%o) in organisms relative to those that obtain nitrogen through nitrogen fixation and/or use fertilizer nitrate as a nitrogen source. Pigment and lipid biomarkers have been used to indicate the occurrence of organic matter enrichment and/or hypoxia; for example, fucoxanthin and zeaxanthin in sediment may reflect enhanced input of diatoms and cyanobacteria, respectively, while isorenieratene and farnesol reflect oxidation of reduced sulfur in the euphotic zone of the water column. Also sterols, fatty acids and alcohols have been used to discriminate different taxa to identify changes in plankton composition, which in turn provide a powerful tool to infer the degree of oxygen depletion in the water column (Gooday et al., 2009).

\section{Scaling-up the results from coastal hypoxia studies}

Coastal hypoxia is indeed a challenging topic to deal with, and the studies involve the integration of multi-disciplinary approaches as well as a combination of observations and model simulations. On one side, coastal hypoxia is affected by changes in watershed properties through coastal eutrophication (e.g. freshwater influx together with land-source nutrients, labile/marine and terrestrial organic materials). On the other side, changes in global forcings may also be important; the atmosphere can impact coastal hypoxia by changing the surface layer heat budget, wind-induced turbulent mixing, and stratification (Fig. 4). Moreover, the dimension and severity of coastal hypoxia are regulated by the variability of ocean circulation, which in turn, is affected by the changing climate (Fig. 4). Thus, the evolution and character of coastal hypoxia are tuned by the complex and interactive combinations of natural and anthropogenic forcings at regional scales (e.g. bio-geography and socio-economic factors), and the ultimate fate of a coastal hypoxic system depends on the regional manifestations of the above-mentioned forcing factors across different spatial and temporal scales.

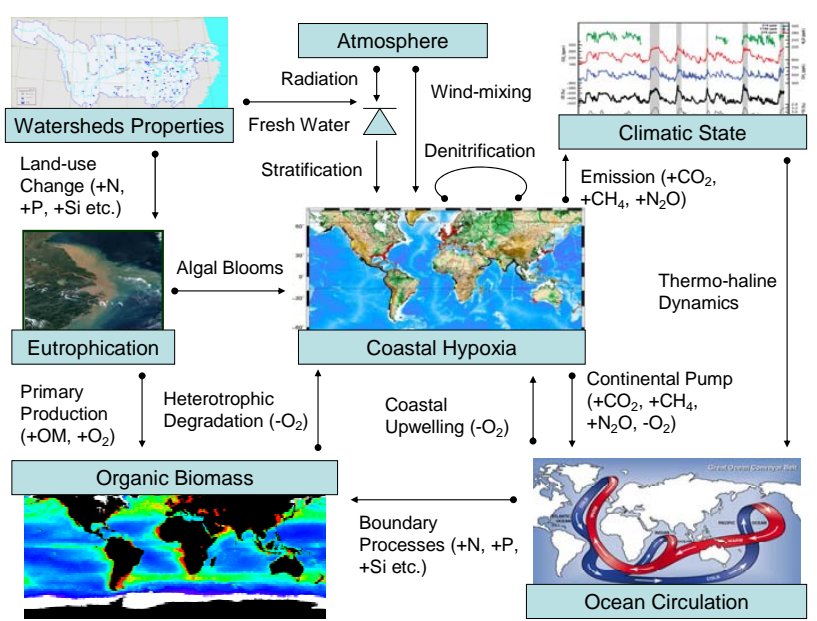

Fig. 4. Schematic view of hypoxia in the global coastal ocean, in which critical mechanisms and state of availability of nutrients, coastal hypoxia, marine primary productivity, and effect of climate change are highlighted. In the figure, the boxed variables are linked by a line terminated with a solid arrow head if the correlation is positive or with a circle if the correlation is negative. If a path of connections can be traced back to itself, a feedback loop is formed with circle ends (e.g. denitrication involves complex mechanisms that interact with hypoxia with strong feedbacks to the nitrogen cycle). The amplification and/or regulation of driving forces are displayed with a sign of audio symbol. Usually, stratification in coastal environments is caused, and subsequently maintained, by surface-layer warming and freshwater input from rivers (e.g. buoyancy effect), or excess rainfall (e.g. the monsoon season), a combination that has a more significant effect than any single factor. Changes in land-use, application of chemical fertilizers in agriculture and hydrographic engineering (e.g. damming) can induce variations in freshwaters and nutrients influx to the adjacent marine waters. An increase in deposition flux of organic matter, either labile (e.g. plankton detritus from in situ production) or refractory (e.g. soil organic materials from watersheds), or both can stimulate heterotrophic metabolisms (e.g. respiration) and chemoautotrophy (e.g. oxidation of ammonium) in the deeper part of the water column and bottom sediments, using oxygen as electron acceptor. Climate state affects the variability of ocean circulation, and hence the development of coastal hypoxia through boundary circulation shelf/coast interactions. All these dynamic processes affect the inventory of dissolved oxygen in the coastal environment, and hence the fate of hypoxia; the combination of different processes often has a more profound impact than any single factor on the persistence of coastal hypoxia. In terms of feedbacks to the Earth System, coastal hypoxia is a source of trace gas species (e.g. $\mathrm{CH}_{4}$ and $\mathrm{N}_{2} \mathrm{O}$ ) to the atmosphere and open ocean, and in extreme cases like in the Gulf of Mexico, $\mathrm{CH} 4$ concentrations in surface waters are up to 1000 times saturation with respect to atmospheric equilibrium (Solomon et al., 2009), due to the escape of hydrate bubbles from marine seeps. The sub-figures are from JGOFS/IGBP (Web-site: http://www1.whoi.edu/index.html), NASA (Web-site: http://science.nasa.gov/headlines/y2004/05mar_ arctic.htm) and IPCC Synthesis Report 2007 (cf. Jansen et al., 2007). 
A key issue addressed by SCOR Working Group \#128 was the natural variability in, and/or anthropogenic influence on, coastal hypoxia and the consequences of these environmental fluctuations for ecosystems. We explored whether studies of coastal hypoxia could be scaled up temporally and spatially across the different geographic and oceanographic settings. It should be noted that by doing this, we had to use approaches such as integration and extrapolation in order to evaluate the role of regional biogeochemical and ecosystem functions at a global scale. However, it should also be kept in mind that the consequences of global change on regional biogeochemical cycles and food-web dynamics can be amplified as coastal hypoxia evolves.

Eutrophication and coastal hypoxia are linked through the heterotrophic degradation of organic matter, remineralization of nutrients and re-oxidation of reduced metabolites (Fig. 1). The organic matter that fuels heterotrophic respiration can be derived from land (i.e. riverine input) or in situ primary production. Low dissolved oxygen in the water column can be the result of upwelling of deep oceanic waters toward the coast, in which the low oxygen waters are usually characterized by high nutrient levels (Fig. 1). Global warming linked to anthropogenic $\mathrm{CO}_{2}$ accumulation in the atmosphere will regulate the development of ocean-wide hypoxia on decadal to millennial time scales (Shaffer et al., 2009). Increased stratification due to surface layer warming may enhance degassing of oxygen from the sea surface to the atmosphere. Riverine influx in summer may also provide warm surface waters to the coast, owing to the more rapid warming over the watersheds, causing enhanced coastal stratification as well (i.e. due to the density difference). In addition, large rivers carry into the adjacent coastal environment a huge amount of plant nutrients that can fuel photosynthesis of phytoplankton, the heterotrophic metabolism of bacteria can be also stimulated owing to an increase in photosynthetic and terrestrial organic matter. When the stratification is destroyed by wind-induced mixing and/or changes in circulation, greenhouse gas species (e.g. $\mathrm{CO}_{2}, \mathrm{CH}_{4}$, and $\mathrm{N}_{2} \mathrm{O}$ ) accumulated in hypoxic waters beneath the stratified surface layer can be released into the atmosphere, potentially having a considerable feedback to climate change. It has been suggested that coastal hypoxic areas are important contributors to the atmospheric inventory of long-lived greenhouse gases (Naqvi et al., 2000, 2009; De Bie et al., 2002; Zhang et al., 2008). Coastal hypoxia can also influence the oceanic inventory of dissolved oxygen, nutrients and other greenhouse gases through exchange with open ocean waters and down-welling.

Several types of modeling approaches, from simple to complex simulations, have significantly contributed to improve our understanding of diverse aspects of hypoxia (Peña et al., 2010). Models have been used to synthesize the observational findings, understand the functioning of the systems and to develop predictive capability. Typically, models developed for specific regions perform well for the particular system for which they were developed, but when applied to other systems, their performance tends to be poor even after re-parameterization. However, the recent development of a generic ecological model (i.e. GEM) for estuaries integrates biological and physical processes in a simulation of basic ecosystem dynamics for generic application to coastal waters (cf. Blauw et al., 2009). This model has been applied in a range of scenario studies, which have formed the basis for several major policy and management decisions and infrastructural developments in coastal zones with different hydrographic and geographic nature.

\section{Integration of biogeochemistry and ecosystems}

The degree to which biogeochemical cycling is linked to food-web dynamics is central to determining the impact of hypoxia on the functioning and provision of services by coastal ecosystems and feedbacks to global climate change. One of the critical issues is the efficiency and role of areas with depleted dissolved oxygen on the biogeochemical dynamics (e.g. nutrient regeneration) and vice versa, that affects the ratio between recycled and new production in coastal environments. A positive feedback occurs when low DO conditions inhibit both nitrification - denitrification and phosphorus burial, thereby promoting more efficient benthic recycling of $\mathrm{N}$ and $\mathrm{P}$, which stimulates phytoplankton growth/sinking and associated bottom water DO depletion (e.g. Middelburg and Levin 2009; Kemp et al., 2005, 2009). This, in turn, affects the whole ecosystem from microbes to top predators through trophic interactions (Ekau et al., 2009; Levin et al., 2009). Because hypoxia also occurred in the geological past, it is important to determine the fate of carbon cycling relative to oxygen depletion over considerable time scales (e.g. $10^{2}-10^{3}$ years) (cf. Gooday et al., 2009). There are limited data sets available on the coupling of hypoxia and biogeochemistry, and particularly on the processes that bridge remineralization and food-web dynamics. Likewise, there are few models that specifically address the effect of hypoxia on a marine ecosystem (Peña et al., 2010). Hypoxia models differ markedly in the level of complexity and temporal and spatial resolutions. Biogeochemical models that include the oxygen cycle may use relatively simple mathematic formulations (e.g. modules) for food web interactions and organisms other than phytoplankton. These formulations range from simple NPZD-type models (i.e. Nutrient, Phytoplankton, Zooplankton, and Detritus) to multi-nutrients, multiple phytoplankton and zooplankton components, and sizestructured ecosystem models.

At present, the stoichiometric relationship between oxygen, carbon and other macro- and micro-nutrients varies over space and time, given the complex character of coastal hypoxia, including different remineralization and burial efficiencies of organic carbon and other biogenic elements. This can result in decoupling of nutrients and trace elements in the 
biogeochemical cycles and changes in apparent nutrient limitation to photosynthesis. Hypoxia-induced changes in nutrient ratios may have far reaching ecological consequences via alterations of primary producer communities, including the proliferation of harmful algae. Data in the literature on the ratio between carbon and other nutrient species indicate that the frequency and significance of oxygen-depleted conditions in areas affected by anthropogenic activities can be more severe than in natural systems (Diaz and Rosenberg, 2008; Middelburg and Levin, 2009). For instance, climate model experiments suggest that OMZs may be sensitive to the evolution of the carbon-to-nitrogen ratio in a warming atmosphere, with a projected expansion of the marine dead zones having severe potential implications for oxygensensitive nutrient recycling (Oschlies et al., 2008).

Hence the overall deterioration of ecosystems affected by coastal hypoxia could be wrongly estimated, if evaluation is only based on short-term studies. Studies of episodic hypoxia events do not usually permit the consequences of such events on food-web structure to be fully assessed, and the ultimate effect on ecosystems has not been properly determined. Recent insight into the non-linear links between temperature, oxygen and $\mathrm{CO}_{2}$ on the scope for growth of marine organisms also opens a new way of investigating the response of ecosystems to hypoxia variability (Pörtner and Knust, 2007; Pörtner and Farrell, 2008). Thus the up-scaling of stoichiometry of carbon and other macro- and/or micronutrients at different temporal and spatial scales should be viewed with caution.

\section{Impact of coastal hypoxia on pelagic fisheries and economics}

Hypoxia affects several different aspects of coastal ecosystems such as the food-web structure, habitat loss and recruitment of fishery species. These changes, in turn, may have a profound impact on social (i.e. traditional catch versus mariculture) and economic sectors, including tourism in addition to fisheries. The feedback of declining fish populations on carbon and nutrient cycles is poorly understood but expected to be highly significant (cf. Ekau et al., 2009; Jennings and Wilson, 2009). It is known that depletion of dissolved oxygen in near-bottom waters can damage the benthic fauna by destroying habitats, increasing mortality and reducing food resources, which in turn imposes a negative effect on the life history of fish. Under low-oxygen conditions, the physiological processes and life cycles of biota can be disrupted (Table 1). Water-column hypoxia affects reproduction, either because fish avoid low oxygen waters for spawning, or because sperm are inactivated or the eggs will not hatch (Nissling and Westin, 1997). Hypoxia in the coastal environment can alter the development (e.g. physiology and life cycle), recruitment, patterns of species distribution and migration (cf. Bertrand et al., 2008) in coastal upwelling (e.g. Peru coast) as well as other areas, ultimately affecting the evolution of species. Adult nektonic species may avoid areas of low DO waters and develop adaptive migrational strategies. Euphausiids, embryos, larvae and juveniles are less mobile and subject to damage when the concentration of DO is too low in the water column. Thus, changes in average DO levels and the amplitude of variability can have different impacts on the survival and composition of different species in an ecosystem, with consequent changes in trophic relationships and productivity. Moreover, reduction of DO and an increase in the areal extent of hypoxia can lead to cascading effects on benthic as well as pelagic species, including community and food-web structure reorganization (Bograd et al., 2008; Stramma et al., 2010). These latter effects are of particular concern in the fisheries of the coastal ocean where pelagic and benthic processes are usually tightly coupled. Hypoxia in coastal near-bottom waters impacts the benthic fauna by favoring mostly low-oxygen resistant species, thus reducing the diversity for whole taxons. The threshold level of dissolved oxygen for the survival and metabolism seems higher for pelagic species (e.g. fish) than benthic fauna (e.g. crustacean and mollusks), because nektonic individuals can escape from hypoxic waters while sessile species have had to adapt to the low DO conditions, sometimes via specific enzyme metabolisms, or die. Low DO levels can severely impact egg development leading to retarded hatching in fish or complete quiescence in copepods (Ekau et al., 2009). Besides the direct lethal effects of hypoxia, sub-lethal responses to low DO concentrations, such as the reduction of egg production, food-intake, sex-selection and other stress symptoms (e.g. schooling), can also have an important impact on the population and community dynamics of ecosystems.

In shallow-water environments, the surface layer is used as a refuge for planktonic organisms when hypoxia occurs in near-bottom waters and hypoxia compresses the vertical and horizontal dimensions of living space; in deep-water environments (e.g. eastern boundary upwelling systems), organisms such as copepods, squids or certain fish species (e.g. horse mackerel, hake or gobies in the Benguela upwelling system off Namibia) (Ekau at al., 2009) have developed vertical migration strategies, and are able to migrate into and out of low oxygen water masses as a means to cope with low oxygen concentrations.

In summary, at basin-wide macro-scales and at the ecosystem level, hypoxia can constrain the distributions of fish species both vertically and horizontally, can force organisms to depart from their normal behavior (e.g. through migration and reproduction), and can change the predator-prey relationships. At sub-basin meso-scales and at the organism level, hypoxia will cause changes in physiology (e.g. metabolism and growth rate) and alter life-cycle performance (e.g. larval settlement of benthic species) and vulnerability to perturbations (e.g. diseases and toxicity). 
Table 1. Comparison of behaviors of biota in marine areas affected by coastal hypoxia.

\begin{tabular}{|c|c|c|}
\hline Category & Description of behavior & Examples \\
\hline \multicolumn{3}{|l|}{ Pelagic systems } \\
\hline Up-welling region & $\begin{array}{l}\text { Change in vertical migration of pelagic } \\
\text { species, increase in possibility of prey - } \\
\text { predator encounter within the compressed } \\
\text { habitats and reduction of bio-mass }\end{array}$ & $\begin{array}{l}\text { Benguela Current - Namibia, Humboldt } \\
\text { Current - Peru }\end{array}$ \\
\hline Large river estuary & $\begin{array}{l}\text { Increase in ratio of heterotrophic bacteria } \\
\text { to autotrophic species, reduction of fish } \\
\text { biomass, and change in biodiversity and } \\
\text { dominance of economic species }\end{array}$ & $\begin{array}{l}\text { Changjiang (Yangtze River) - East China } \\
\text { Sea, Mississippi River - Gulf of Mexico, } \\
\text { Susquehanna River - Chesapeake Bay }\end{array}$ \\
\hline Fjord and semi-enclosed basins & $\begin{array}{l}\text { Increase in recycled relative to new pro- } \\
\text { duction and change in community compo- } \\
\text { sition, enhanced diversion of energy flows } \\
\text { into microbial pathways to the detriment } \\
\text { of higher trophic levels }\end{array}$ & Baltic Sea, Black Sea \\
\hline \multicolumn{3}{|l|}{ Benthic fauna } \\
\hline Up-welling region & $\begin{array}{l}\text { Habitat compression, increase in mortal- } \\
\text { ity of benthic species, and shift of food } \\
\text { web structure }\end{array}$ & $\begin{array}{l}\text { California Current off Oregon, Central } \\
\text { Peru system }\end{array}$ \\
\hline Large river estuary & $\begin{array}{l}\text { Low abundance and species biodiversity, } \\
\text { change in benthic fauna composition, and } \\
\text { size spectrum }\end{array}$ & $\begin{array}{l}\text { Changjiang (Yangtze River) - East China } \\
\text { Sea, Mississippi River - Gulf of Mexico }\end{array}$ \\
\hline Fjord and semi-enclosed basins & $\begin{array}{l}\text { Change in redox conditions and mineral- } \\
\text { ization for nutrients and trace elements, } \\
\text { habitat compression, and increase in nu- } \\
\text { trient flux from sediment to near-bottom } \\
\text { waters }\end{array}$ & Baltic Sea, Black Sea \\
\hline
\end{tabular}

\section{Feed-back to the earth system}

One of the distinguishing characteristics of coastal hypoxia is its potential for a strong feed-back to climate through changes in atmospheric composition, e.g. climate-active gases (Fig. 4). The ocean is an important source of $\mathrm{N}_{2} \mathrm{O}$ to the atmosphere, but a moderate contributor to the atmospheric $\mathrm{CH}_{4}$ budget. The production and consumption of both gases are strongly dependent on the ambient oxygen level, and their emissions to the atmosphere per unit area from regions experiencing hypoxia are higher than the oceanic average values (Table 2 and Fig. 5). Thus, the ongoing change (i.e. general decline) in oxygen concentration in the ocean may affect these fluxes.

Most of the $\mathrm{CH}_{4}$ accumulating in bottom waters is believed to be derived from anoxic sediments (Reeburgh, 2007), and so the DO/redox state of bottom waters is expected to affect the rate and depth of production of $\mathrm{CH}_{4}$ in the sediment as well as its oxidative loss in water and in the upper sedimentary column. All hypoxic systems accumulate $\mathrm{CH}_{4}$ to varying degrees depending upon the basin morphology and the extent of oxygen deficiency in the water column (Naqvi et al., 2009). Maximal build-up (i.e. at $\mu \mathrm{M}$ levels) occurs in sulfide bearing waters of semi-enclosed basins such as the Black Sea and Cariaco Basin, followed by (i.e. in tens of $\mathrm{nM}$ ) silled basins overlain by hypoxic/suboxic waters (e.g. in the Gulf of California). Along the open coasts (e.g. up-welling areas), $\mathrm{CH}_{4}$ content of bottom waters responds to changes in ambient DO as well. Again the sulfidic bottom waters have the highest $\mathrm{CH}_{4}$ concentrations at hundreds of $\mathrm{nM}$ over the Namibian shelf (Scranton and Farrington, 1977), but comparably high concentrations could also occur in hypoxic/suboxic bottom waters not containing hydrogen sulfide, e.g. in the northern Gulf of Mexico and off the Changjiang Estuary (Kelley, 2003; Zhang et al., 2008). However, there are two factors that introduce complexities in the interpretation of $\mathrm{CH}_{4}$ data from coastal settings. First, the regions of freshwater influence that are often sites of coastal hypoxia (e.g. Gulf of Mexico and Indian shelf), receive large allochthonous inputs of $\mathrm{CH}_{4}$ from coastal wetlands (Jayakumar et al., 2001). Second, despite the prevailing normoxic conditions, $\mathrm{CH}_{4}$ production still occurs in the surface layer by processes that are still not fully understood (Scranton and Brewer, 1977; Reeburgh, 2007; Karl et al., 2008). As hypoxia, both natural and human induced, occurs in regions of high primary productivity where in situ $\mathrm{CH}_{4}$ production rate is also high, it is difficult to differentiate such production from enhanced emissions from the sediments (Scranton and Farrington, 1977). 
Table 2. Emission fluxes of $\mathrm{CH}_{4}$ and $\mathrm{N}_{2} \mathrm{O}$ from major coastal hypoxic zones.

\begin{tabular}{|c|c|c|}
\hline Region & Range & References \\
\hline \multicolumn{3}{|l|}{$\mathrm{CH}_{4}$ flux $\left(\mu \mathrm{mol} \mathrm{m}{ }^{-2} \mathrm{~d}^{-1}\right)$} \\
\hline Northwest Africa (i.e. Canary Current) & $0.4-1.7$ & Kock et al., 2008 \\
\hline Southwest Africa (i.e. Benguela Current) & $3-752$ & Scranton and Farrington, 1977 \\
\hline $\begin{array}{l}\text { Northern Indian Ocean } \\
\text { (i.e. Arabian Sea and Bay of Bengal) }\end{array}$ & $\begin{array}{r}30.9-367 \\
0.2-24.9 \\
0-63.7\end{array}$ & $\begin{array}{l}\text { Bange et al., } 1998 \\
\text { Berner et al., } 2003 \\
\text { Naqvi et al., } 2005\end{array}$ \\
\hline $\begin{array}{l}\text { Eastern North Pacific } \\
\text { (i.e. California Current) }\end{array}$ & $\begin{array}{r}0.77-3.0 \\
0.5-5.9\end{array}$ & $\begin{array}{l}\text { Sansone et al., } 2001 \\
\text { Sansone et al., } 2004\end{array}$ \\
\hline $\begin{array}{l}\text { Eastern South Pacific } \\
\text { (i.e. Humboldt Current) }\end{array}$ & $0.86-18.7$ & Farias et al., 2009 \\
\hline Black Sea & $29-53$ & Amouroux et al., 2002 \\
\hline $\begin{array}{l}\text { Changjiang (Yangtze River) } \\
\text { Estuary and East China Sea }\end{array}$ & $0.02-440$ & Zhang et al., 2008 \\
\hline \multicolumn{3}{|l|}{$\mathrm{N}_{2} \mathrm{O}$ flux $\left(\mu \mathrm{mol} \mathrm{m}{ }^{-2} \mathrm{~d}^{-1}\right)$} \\
\hline $\begin{array}{l}\text { Northern Indian Ocean } \\
\text { (i.e. Arabian Sea and Bay of Bengal) }\end{array}$ & $\begin{array}{r}0.3-7.1 \\
3.9-8.2 \\
0.1-351\end{array}$ & $\begin{array}{l}\text { Bange et al., } 1998 \\
\text { Bange et al., } 2001 \\
\text { Naqvi et al., } 2005\end{array}$ \\
\hline $\begin{array}{l}\text { Eastern North Pacific } \\
\text { (i.e. California Current) }\end{array}$ & $-0.8-5.5$ & Cohen and Gordon, 1978 \\
\hline $\begin{array}{l}\text { Eastern South Pacific } \\
\text { (i.e. Humboldt Current) }\end{array}$ & $\begin{array}{l}-9.8-195 \\
-2.3-42.9\end{array}$ & $\begin{array}{l}\text { Cornejo et al., } 2007 \\
\text { Farias et al., } 2009\end{array}$ \\
\hline Baltic Sea & $2.75-53.8$ & Rönner, 1983 \\
\hline Black Sea & $1.6-5.2$ & Amouroux et al., 2002 \\
\hline $\begin{array}{l}\text { Changjiang (Yangtze River) } \\
\text { Estuary and East China Sea }\end{array}$ & $-0.7-97.5$ & Zhang et al., 2008 \\
\hline
\end{tabular}

Due to the oxidative loss, accumulation of $\mathrm{CH}_{4}$ in bottom waters generally leads to only a modest increase in its efflux to the atmosphere. However, in the Changjiang (Yangtze River) Estuary, Zhang et al. (2008) found the sea-to-air flux of $\mathrm{CH}_{4}$ to be as high as $250-400 \mu \mathrm{Mol} \mathrm{m}^{-2} \mathrm{~d}^{-1}$ in the areas of hypoxia, which is twenty times higher than the flux from shelf mixed water (e.g. $10-15 \mu \mathrm{Mol} \mathrm{m}{ }^{-2} \mathrm{~d}^{-1}$ ) of East China Sea and up to three orders of magnitude higher than the flux from surface waters of the Kuroshio $\left(<0.5 \mu \mathrm{Mol} \mathrm{m}^{-2} \mathrm{~d}^{-1}\right)$. It should be noted that sea-to-air flux of $\mathrm{CH}_{4}$ in the area affected by the Changjiang effluent plums is higher than the water-to-air flux in the river itself. As already pointed out, the oceanic contribution to the atmospheric $\mathrm{CH}_{4}$ budget is relatively insignificant at $<2 \%$ (cf. Reeburgh, 2007), and so unless $\mathrm{CH}_{4}$ emissions from the global ocean are enhanced by an order of magnitude or more, expansion/intensification of coastal hypoxic zones is unlikely to match increases in atmospheric $\mathrm{CH}_{4}$ fluxes from other anthropogenic sources (Naqvi et al., 2009).
The situation is different for $\mathrm{N}_{2} \mathrm{O}$, which is formed mostly in the water column, as opposed to a large part of $\mathrm{CH}_{4}$ production occurring in the sediments, both by oxidizing (e.g. nitrification) and reducing (e.g. denitrification) processes. Moreover, $\mathrm{N}_{2} \mathrm{O}$ loss in the water column is much more restricted. Nitrification is an aerobic process, but low DO levels cause an enhancement of $\mathrm{N}_{2} \mathrm{O}$ yield presumably through nitrifier - denitrification (Yamagishi et al., 2007). Anaerobic denitrification involves both production and consumption of $\mathrm{N}_{2} \mathrm{O}$ (Codispoti and Christensen, 1985). Thus, while $\mathrm{N}_{2} \mathrm{O}$ is lost through its reduction to $\mathrm{N}_{2}$ within the cores of the open ocean OMZs and in deep (e.g. anoxic) waters of semi-enclosed basins, highest concentrations (ca. tens of $\mathrm{nM}$ ) are always found at the edges of the OMZs, thereby making them strong net sources of $\mathrm{N}_{2} \mathrm{O}$ (Table 2) (Codispoti and Christensen, 1985). The extent of this build-up at the normoxic - anoxic boundary in the semi-enclosed anoxic basins is much smaller, for reasons that are not yet clear (Naqvi et al., 2009). However, naturally formed hypoxic systems that periodically experience sulfidic conditions at shallow depths 


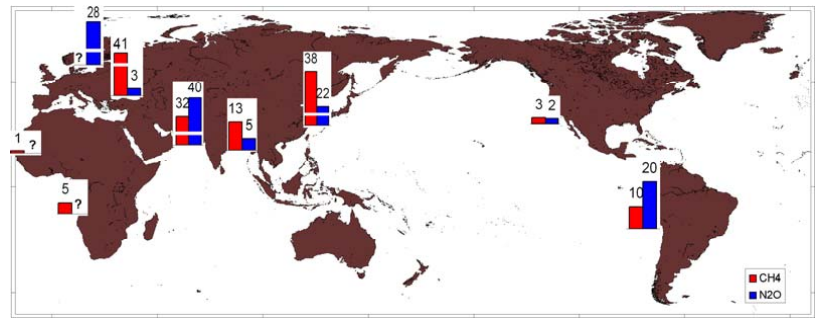

Fig. 5. Sea to air emission flux of $\mathrm{CH}_{4}$ and $\mathrm{N}_{2} \mathrm{O}$ (unit: $\mu \mathrm{mol} \mathrm{m} \mathrm{m}^{-2} \mathrm{~d}^{-1}$ ) from major coastal hypoxic environments of the world, including upwelling systems (i.e. Canary Current, Benguela Current, California Current, and Humboldt Current), Northern Indian Ocean (i.e. Arabian Sea and Northern Bay of Bengal), semi-enclosed basins (e.g. Black Sea and Baltic Sea), and off large river mouths and in adjacent shelves (e.g. Changjiang Estuary and East China Sea Shelf). See Table 2 for details of data source. For comparison, $\mathrm{CH}_{4}$ and $\mathrm{N}_{2} \mathrm{O}$ concentrations in the open ocean not underlain by oxygen-depleted waters are close to or slightly supersaturated (i.e. by a few percent) with reference to their atmospheric levels.

along open coasts, such as the western Indian continental shelf, are distinguished by abnormally high $\mathrm{N}_{2} \mathrm{O}$ build-up (i.e. up to hundreds of $\mathrm{nM}$ ), seemingly due to production via denitrification (Naqvi et al., 2000 and 2006). Moreover, since this production occurs very close to the surface, it supports high fluxes of $\mathrm{N}_{2} \mathrm{O}$ to the atmosphere. For example, it is estimated that the Indian shelf itself could emit as much as $0.4 \mathrm{Tg} \mathrm{N}_{2} \mathrm{O}$ to the atmosphere annually (Naqvi et al., 2000).

Most of the available data on $\mathrm{N}_{2} \mathrm{O}$ from hypoxic marine environments comes from natural systems, although it is likely that some of these systems, particularly the Indian shelf, have also been significantly impacted by human activities (Naqvi et al., 2000). In the few coastal hypoxic systems that are mostly anthropogenically formed and have been sampled for $\mathrm{N}_{2} \mathrm{O}$, substantial enhancement of $\mathrm{N}_{2} \mathrm{O}$ concentration has been reported. Coastal hypoxia due to eutrophication are hot spots for $\mathrm{N}_{2} \mathrm{O}$ release not only because of low oxygen conditions, but also because of high nitrogen loadings and fluxes (De Bie et al., 2002). For instance, off the mouth of Changjiang in the East China Sea, concentrations of $\mathrm{N}_{2} \mathrm{O}$ in the hypoxic layer (i.e. $\mathrm{O}_{2}<63 \mu \mathrm{M}$ ) can be as high as $40-60 \mathrm{nM}$ as compared to $10-20 \mathrm{nM}$ in the overlying surface waters and $5-10 \mathrm{nM}$ at the surface further offshore over the open shelf (Zhang et al., 2008). Accordingly, the seato-air flux of $\mathrm{N}_{2} \mathrm{O}$ from the region is $50-100 \mu \mathrm{mol} \mathrm{m}^{-2} \mathrm{~d}^{-1}$, an order of magnitude higher than the $\mathrm{N}_{2} \mathrm{O}$ flux for shelf mixed water of the East China Sea (i.e. $<10 \mu \mathrm{mol} \mathrm{m}^{-2} \mathrm{~d}^{-1}$ ) and Kuroshio Surface Waters (i.e. $<5 \mu \mathrm{mol} \mathrm{m} \mathrm{m}^{-2} \mathrm{~d}^{-1}$ ) (Zhang et al., 2008). Even higher fluxes are expected from hypoxic zones when the stratification is eroded by mixing caused by advection and wind/wave induced turbulent mixing, particularly during extreme events such as storms (Naik et al., 2008). This applies equally well to other greenhouse gases (e.g. $\mathrm{CO}_{2}$ and $\mathrm{CH}_{4}$ ). The oceanic contribution to the atmospheric $\mathrm{N}_{2} \mathrm{O}$ inventory is globally significant, with the regions of coastal upwelling/low DO serving as disproportionately large sources (Codispoti et al., 1992; Naqvi et al., 2000; Bange et al., 2001; Nevison et al., 2004). Thus, the ongoing intensification and expansion of coastal hypoxic zones (Diaz and Rosenburg, 2008) is likely to lead to a significant increase in $\mathrm{N}_{2} \mathrm{O}$ emission from the ocean. However, a reliable quantitative prediction of this increase is not possible at present because of uncertainties concerning the mechanisms of $\mathrm{N}_{2} \mathrm{O}$ production as well as insufficient data from key coastal regions.

The role of expanding shelf hypoxia on the global $\mathrm{CO}_{2}$ budget also needs to be considered. Recent work has shown that shelf systems are a net $\mathrm{CO}_{2}$ sink with a magnitude of $0.36 \mathrm{Pg} \mathrm{Cyr}^{-1}$ (Chen and Borges, 2009) compared to an ocean $\mathrm{CO}_{2}$ sink of $1.8 \pm 0.7 \mathrm{Pg} \mathrm{C} \mathrm{yr}^{-1}$ (Doney et al., 2009). The predicted expansion of shelf hypoxia, both natural and anthropogenically forced, will reduce the magnitude of the recently estimated $\mathrm{CO}_{2}$ sink. The magnitude of this factor will depend on changing rates of biological production and remineralization, redox conditions and rates of physical upwelling.

In summary, profiles of $\mathrm{CH}_{4}$ and $\mathrm{N}_{2} \mathrm{O}$ reveal high concentrations in coastal hypoxic waters, which can considerably enhance the emission to the atmosphere, especially when stratification is broken down by turbulent vertical mixing. Such high $\mathrm{CH}_{4}$ and $\mathrm{N}_{2} \mathrm{O}$ stocks in deep and near-bottom waters of coastal hypoxic regions can also be exported to the open ocean by circulation and dynamic processes across the shelf break, an important component of the "Continental Shelf Pump" for carbon and other nutrients (Fig. 4). Thus, although eutrophication may induce $\mathrm{CO}_{2}$ uptake through enhanced photosynthesis (e.g. phytoplankton blooms), the development of coastal hypoxia, sometimes the "Twin Sister of Eutrophication", can be accompanied by production of a large amount of $\mathrm{CH}_{4}$ and $\mathrm{N}_{2} \mathrm{O}$, which in turn has significant feed-backs to the atmosphere and the ocean interior, and hence contribute to changes in the global climate (Fig. 4).

\section{Key questions and topics for future research}

Coastal hypoxia can be considered as a transitional state of marine ecosystems passing from normoxia to anoxia, and vice versa, although complex forcing and feed-back relationships can be involved, like threshold and hysteresis in the shift from one quasi-stable regime to another (Fig. 6). Key findings of SCOR Working Group \#128 offer insights that are relevant for both observational work and modeling. However, our currently limited knowledge does not allow a direct link to be established between modern hypoxia and geological records, in part owing to uncertainties in our understanding of biogeochemical processes associated with coastal hypoxia and of the physical processes involved in the transport of water mass properties, in eastern boundary 


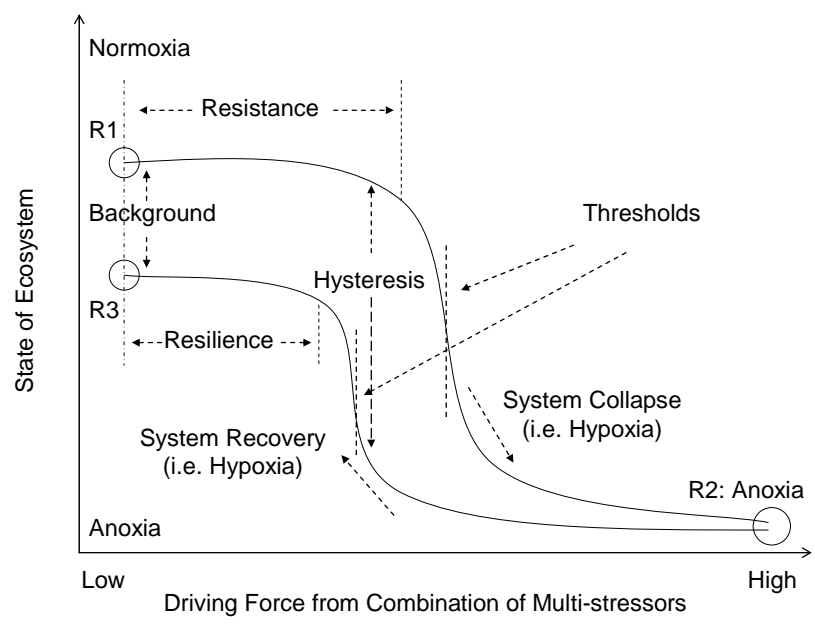

Fig. 6. Conceptual diagram for the response of ecosystems to the conditions of dissolved oxygen in the coastal ocean, along the trajectories of normoxia to hypoxia/anoxia and vice versa, with hypoxia as transitional state. In the figure R1, R2 and R3 represent different regime states of the ecosystem that can change from one to another. In most cases, the ecosystem is affected by a combination of multi-stressors with specific regional nature rather than by any single forcing, and the system response is not linear. The resistance, hysteresis, threshold, resilience and change in background conditions are characters that dictate the response processes of the ecosystem to the external forcing and/or pressure (e.g. either natural and/or anthropogenic, or both), which is usually very dynamic in the coastal environment. When the system response passes over a threshold (e.g. from R1 to R2), a new ecosystem regime can be reached (i.e. regime shift); in the case of relief from external stressors, the recovery of the ecosystem will follow another pathway and eventually, can have a different background situation (i.e. R3). The figure is a modification based on the work by Tett et al., 2007, van de Koppel et al., 2009, and Kemp et al., 2009.

current systems in particular. Some of the key issues center on questions such as evolution of hypoxia and the responses of ecosystems. The following observations and hypotheses merit future attention:

- With respect to nutrient dynamics in coastal hypoxia, the stoichiometry and different rates of cycling between macro- and/or micro-nutrients and their link to the carbon cycle are of critical importance in determining consequences for ecosystems. This in turn will dictate the change in food-web structure and the subsequent biogeochemical balance between cycling of carbon within the system, export to the open ocean, and feed-back mechanisms to the atmosphere.

- Although the external nutrient supply from land-sources is important, the intrinsic factors that influence biogeochemical cycling in coastal hypoxic systems are critical. We hypothesize that the development of hypoxia is determined by the rate and magnitude of mineralization of macro and micro-nutrient species and in partic- ular by their retention in the water column. In hypoxic and anoxic sediments, the recycling fluxes of inorganic phosphorus and nitrogen are elevated under low oxygen conditions, thus providing a positive feed-back to the biological processes controlling primary production and subsequent hypoxia formation. For nutrient supply in upwelling systems, these processes include mixedlayer water residence time, climatic forcing such as the monsoons or equatorial oceanic waves, and the variability and characteristics of deep water that up-wells over the shelf (e.g. concentration of DO).

- It has been realized that coastal hypoxia can have a strong impact on the function of other compartments of the Earth System in the context of global change. For instance, data from this SCOR Working Group \#128 have shown that sea to air emission flux of certain greenhouse gases from coastal hypoxic regions can be much stronger than in other parts of ocean, which in turn, affects the radiative heat balance of the atmosphere. Also, chemical species produced in hypoxic waters (e.g. $\mathrm{CH}_{4}$, $\mathrm{N}_{2} \mathrm{O}, \mathrm{Fe}$ (II), nutrients and $\mathrm{CO}_{2}$ etc.) can be advected to the open ocean through the mechanism of the continental shelf pump.

Regarding the issue of multi-forcings (i.e. stressors) and responses of the coastal environment such as hypoxia, the marine ecosystem is poorly known compared with its terrestrial counterpart. The relative importance of the processes that underpin coupling between biogeochemistry and physics and the driving mechanisms, either regional or remote or both, will vary temporally and spatially. These processes, which regulate the export of nutrients and carbon, include the differential rates of degradation of organic matter in subsurface waters. Each of these, in turn, will be determined by a range of factors such as remineralization rates, foodweb interactions and composition and properties of organic matter and their transformation (e.g. sinking and export efficiency) (Table 3). Sensitivity analysis using coupled physical and biogeochemical models can be performed for evaluating separately the roles of increased freshwater discharge (i.e. buoyancy forcing) and increased nutrient loading from the watershed on the extent and duration of hypoxic conditions.

Given the projected trend of global change, the shortand long-terms impacts of climate states on coastal hypoxia include warming, altered rainfall and freshwater discharge from adjacent watersheds, water column stratification, reduction of water $\mathrm{pH}$ owing to ocean acidification. These are cross-linked to perturbations from human activities (e.g. change in pollutants and sediment loads, eutrophication, and mariculture) (IPCC, 2007a). The future development of hypoxia in oceanic and coastal waters will inevitably reflect interactions among the multiple effects of climate change, coupled with changing human activities that affect the coastal ocean (Rabalais et al., 2010). Indications 
Table 3. Summary of major types of coastal ecosystems affected by hypoxia with different natural and anthropogenic driving forces.

\begin{tabular}{|c|c|c|c|c|}
\hline Category & $\begin{array}{l}\text { Type of } \\
\text { hypoxia }\end{array}$ & $\begin{array}{l}\text { Natural } \\
\text { forcings }\end{array}$ & $\begin{array}{l}\text { Anthropogenic } \\
\text { factors }\end{array}$ & $\begin{array}{l}\text { Potential impact } \\
\text { on the } \\
\text { ecosystem function }\end{array}$ \\
\hline $\begin{array}{l}\text { Large river estuary } \\
\text { (e.g. Chesapeake Bay, } \\
\text { Mississippi River } \\
\text { and Changjiang) }\end{array}$ & $\begin{array}{l}\text { Episodic and/or } \\
\text { periodic events }\end{array}$ & $\begin{array}{l}\text { Land-source nutrients } \\
\text { influx, change in runoff } \\
\text { affecting stratification }\end{array}$ & $\begin{array}{l}\text { Increase in nutrient } \\
\text { and organic matter loads }\end{array}$ & $\begin{array}{l}\text { Deterioration of habitats, } \\
\text { changes in nutrient ratios } \\
\text { affecting phytoplankton } \\
\text { assemblages }\end{array}$ \\
\hline $\begin{array}{l}\text { Semi-enclosed basin } \\
\text { (e.g. Black Sea } \\
\text { and Baltic Sea) }\end{array}$ & $\begin{array}{l}\text { Periodic and/or } \\
\text { persistent events }\end{array}$ & $\begin{array}{l}\text { Limited water exchange } \\
\text { with open ocean } \\
\text { (e.g. increase in flushing } \\
\text { time) }\end{array}$ & $\begin{array}{l}\text { Nutrient influx from } \\
\text { surrounding land } \\
\text { masses and change } \\
\text { in nutrient ratio }\end{array}$ & $\begin{array}{l}\text { Loss of some benthic } \\
\text { species, release of } \\
\text { toxic chemicals } \\
\text { (e.g. } \mathrm{H}_{2} \mathrm{~S} \text { into water } \\
\text { column) }\end{array}$ \\
\hline $\begin{array}{l}\text { Coastal up-welling } \\
\text { area (e.g. Namibia } \\
\text { and Peru) }\end{array}$ & $\begin{array}{l}\text { Seasonal and/or } \\
\text { persistent events }\end{array}$ & $\begin{array}{l}\text { Equatorial variability } \\
\text { and change in local } \\
\text { circulation pattern } \\
\text { (e.g. coastal trapped } \\
\text { waves, mixing and } \\
\text { Ekman pumping); } \\
\text { interaction of OMZs } \\
\text { with narrow shelf with } \\
\text { seasonal stratification } \\
\text { and high organic matter } \\
\text { flux }\end{array}$ & $\begin{array}{l}\text { Increase in vertical } \\
\text { organic matter } \\
\text { flux related to high } \\
\text { primary production that } \\
\text { can sometimes be related } \\
\text { to nutrient influx } \\
\text { from land-sources }\end{array}$ & $\begin{array}{l}\text { Decoupling of pelagic } \\
\text { and benthic processes, } \\
\text { and loss of benthic } \\
\text { species; habitat limita- } \\
\text { tion and modulation of } \\
\text { sub-thermocline species } \\
\text { life cycle, as well as } \\
\text { periodic strandings of } \\
\text { benthic organisms }\end{array}$ \\
\hline
\end{tabular}

are that ocean deoxygenation (Gilbert et al., 2009; Keeling et al., 2010) and worsening coastal hypoxia (Rabalais et al., 2009,2010 ) are the most likely scenarios under a changing climate. Ocean and terrestrial warming can lead to changes in precipitation and river discharge, increased water column stratification, changes in winds and circulation, reduced oxygen solubility, out-gassing, and enhanced primary production and respiratory rates (i.e. $Q_{10}$ effects).

Oxygen minimum zones occupy large volumes of the intermediate-depth eastern tropical oceans. Climate models predict declines in oceanic dissolved oxygen associated with global warming or increased atmospheric $\mathrm{CO}_{2}$ or both. As a consequence of global climate change, predictions are for oceanic dissolved oxygen to decline (Minami et al., 1999; Shaffer et al., 2009). This lower oxygen concentration will be most noticeable in OMZs as they expand in area and extend into shallower depths (Arrigo, 2007; Riebesell et al., 2007). Ocean models predict declines of $1 \%$ to $7 \%$ in the global ocean $\mathrm{O}_{2}$ inventory over the next century, with declines continuing for a thousand years or more into the future (Keeling et al., 2010). Over longer time scales (ca. 104 $10^{5}$ years), Shaffer et al. (2009) project severe, long-term ocean oxygen depletion, as well as an expansion of ocean oxygen minimum zones. These trends are already apparent in the last five decades. Recent data syntheses by Gilbert et al. (2009) indicate that the number of negative trend oxygen records for ocean waters has significantly increased in the 1976-2000 period relative to 1951-1975. Ocean scientists may inadvertently ignore the $\mathrm{CO}_{2}$ side of the respiration equation, on the unspoken assumption that $p \mathrm{CO}_{2}$ levels are low and are inversely proportional to the $\mathrm{O}_{2}$ concentration via bacterial oxidation of marine organic matter. However, this may no longer be the case as Brewer and Peltzer (2009) predict that increasing atmospheric $\mathrm{CO}_{2}$ concentrations reset ocean chemical relations so that oceanic oxygen minimum zones will grow in size and severity.

Warming can also alter wind patterns with changes in coastal circulation, upwelling, and downwelling that can either aggravate a low oxygen condition or, in fact, alleviate it. Most likely upwelling favorable conditions will reduce open coast oxygen levels through advection of deeper oxygen deficient waters on to continental shelves (Bograd et al., 2008; Stramma et al., 2008, 2010). Most of the eastern boundary current systems (e.g. Benguela, Peru/Chile and California, etc.) are influenced to a large extent by the tropical climate and ocean variability, which make them sensitive to climate change in two ways: (1) regional change in atmospheric circulation may lead to change in upwelling conditions (Bakun and Weeks, 2008), and (2) change in tropical (Vecchi et al., 2006; Yeh et al., 2009) or subtropical (Garreaud and Falvey, 2009) circulation may have a direct impact on the upwelling variability by modifying the energy spectrum of the remote (e.g. equatorial Kelvin wave activity) and local (e.g. atmospheric coastal jet) forcing. An example 
of the increasing hypoxia can be found off the Oregon and Washington coasts, where wind-driven shifts in the California Current system in 2001 and subsequent years altered the long-term pattern of upwelling and resulted in extensive hypoxia along the inner shelf (Grantham et al., 2004; Chan et al., 2008).

Coastal waters are where an increasing human population and its impacts on land use and flux of nutrients from watersheds to the sea will most closely interact with aspects of global climate change. There is evidence for a higher proportion of declining oxygen trends near coastlines (i.e. $<30 \mathrm{~km}$ distance) than in the open ocean in the last five decades, most probably due to runoff of nutrients in the coastal region (Gilbert et al., 2009). In certain parts of the world, atmospheric warming will lead to increased inputs to the coastal zone of river-derived freshwater and nutrients, exacerbating eutrophication, algal blooms, and oxygen demand (Rabalais et al., 2009, 2010). At the same time, anthropogenic inputs of nutrients to coastal waters will increase if only because of increased human population and increased needs for fuel and food. As in the sense of multiple stressors, it will be difficult to differentiate completely the global climate change aspect and the anthropogenic activities aspect of global evolution of eutrophication and associated hypoxia (Rabalais et al., 2010).

Increasing water temperatures alone have the potential to strengthen pycnoclines in estuarine and coastal waters, but lower surface salinity (e.g. from increased freshwater runoff) would be more of a factor in stratifying the water column (Fofonoff and Millard, 1983). A stronger pycnocline (i.e. density differences dictated by a combination of temperature and salinity) should result in less diffusion of oxygen from the upper to the lower parts of the water column. However, shifts in coastal currents may bring cooler waters with low DO, albeit with higher nutrients on to shelf areas.

Increased precipitation will result in more water, sediments and nutrients reaching the coastal zone where they are likely to enhance eutrophication through nutrient-enhanced production, increased stratification, or both (Cloern, 2001). For instance, increased precipitation in the upper part of the Mississippi River watersheds is predicted from climate models (IPCC, 2007b; Milliman et al., 2008). An increase in precipitation there (e.g. $10 \%$ to $30 \%$ per century) should result in increased erosion and loss of phosphorus and increased flux of dissolved inorganic nitrogen, particularly nitrate, through the soils and artificially drained agriculture areas. The combination of increased nutrient loads (i.e. from human activities) and increased freshwater discharge (i.e. from climate change) will aggravate the already high loads of nutrients to coastal waters, strengthen stratification with all other factors remaining the same, and worsen the hypoxia situation (Justic et al., 2003; Rabalais et al., 2009). Reduced precipitation, however, will lower the amount of nutrients and water reaching the coastal zone and, perhaps, lead to oligotrophication and reduced fisheries productivity (Nixon, 2004), or perhaps alleviate hypoxia. The increase or decrease in flow, whichever occurs, and associated changes in the flux of nutrients and water temperature are likely to have important, but as yet not clearly identifiable, influences on hypoxia.

If the frequency of tropical storms and hurricanes increases as a result of increased water temperatures in the lower- to mid-latitudes as predicted in climate change, the mixing of water in coastal habitats will increase and breakdown stratified water columns that support hypoxia. Knutson et al. (2007) predicted a modest $18 \%$ decrease in the frequency of Atlantic hurricanes by the end of the 21st Century and a few percent increase in the intensity of storms. A recent model by Bender et al. (2010) projects nearly a doubling of the frequency of category 4 and 5 storms by the end of the 21 st Century, despite a decrease in the overall frequency of tropical cyclones with the increase projected to occur in the Western Atlantic, north of $20^{\circ} \mathrm{N}$. The impacts of hurricanes and tropical storms on stratification and how much they temporarily alleviate hypoxia in the coastal waters of the northern Gulf of Mexico depend on several factors (Rabalais et al., 2007), which include barometric pressure, wind speed, storm trajectory, forward speed, and circumference of the wind and wave field. If hurricanes occur during the period of hypoxia, then there will only be transient dissipation of hypoxia.

The rates of biological processes, including both photosynthesis and respiration, are expected to increase with higher water temperatures up to a point. For instance, primary production may proceed at a faster rate but will eventually become limited by light (e.g. self-shading) or lack of nutrients. Increased water temperatures will lead to less dissolution of oxygen in water provoking lower oxygen concentrations, which in turn will experience higher respiration rates particularly in the lower water column where enhanced flux of organic matter may result from higher inputs of nutrients to surface waters. These climate-related modifications of physical and biological processes also interact with pollution, over-fishing, exotic species invasions, and various forms of coastal habitat loss. Understanding of hypoxia in the future ocean must involve a holistic perspective that recognizes linkages among various forms of anthropogenic forcing and ecosystem responses.

The case studies of this SCOR WG \#128 indicate complex mechanisms involved in the relationship between causative factors (e.g. conditions that cause hypoxia) and ecosystem responses (e.g. food-web structure and function). Analyses of historical data relating hypoxia and nutrient inputs suggest that response trajectories can be system specific, either simple linear or non-linear, or both (Turner et al., 2008; Conley et al., 2009b; Kemp et al., 2009 and Fig. 6). While there is a socio-economic commitment to remediation of coastal hypoxia (e.g. reducing nutrient loading from the adjacent watersheds), a system specific "threshold" in ecosystem function may exist in the recovery from coastal hypoxia through reduction of nutrient loadings, with a hysteresis and possibility of regime shifts (Fig. 6). In some of the coastal ecosystems 
experiencing multiple perturbations (e.g. species invasion, fishing harvest and climate alteration), the "baseline conditions" (i.e. background in Fig. 6) can be changed when the stressors are released, which leads to situations where complete recovery of hypoxia to pre-disturbed conditions cannot be achieved simply by reducing the driving forces (e.g. nutrient loading) (Van de Koppel et al., 2009; Kemp et al., 2009). Moreover, since an ecosystem usually responds to the external forcings from a combination of stressors and complex interactions within the system, removal of a single forcing factor (e.g. reduction of nutrient input) may not necessarily be followed by the return of the ecosystem to its pristine state.

Testing these processes will require both system specific examinations and multi-disciplinary studies that link biogeochemistry and global change across different oceanographic settings. Several approaches can be proposed:

- Modeling studies to incorporate our understanding of coastal hypoxia in the modern ocean to reconstruct conditions back in time to the beginning of the Anthropocene and to predict future states. Coupled physicalbiogeochemical-ecosystem models will better address several important questions, including causes of the observed worldwide increase in hypoxic conditions, and future changes in the intensity and spread of coastal hypoxia. Model simulations can be used to capitalize on the complementary approaches obtained by previous studies into pulsed anthropogenic perturbations versus sustained climate variability. Considering the rather coarse resolution of the current generation for coupled ocean-atmosphere-biogeochemical models, down-scaling experiments using high-resolution regional models should be promoted in order to provide background materials for the understanding of coastal hypoxia, in particular in the context of climate change.

- Improved experimental and/or observational designs to overcome limitations of individual and discrete studies, and additional measurements that will provide insight into the impact of nutrient enrichment on climate change (e.g. biogenic gases) and biogeochemical cycling (e.g. link between coastal and open ocean). Carefully designed comparative studies among different ecosystems that are affected by coastal hypoxia will help better determine the influence of supply and regeneration of nutrient species on global biogeochemistry. Such approaches rely, however, on innovative technologies (e.g. sensor arrays), and should be managed in a way that links them to circulation models with embedded biogeochemical modules.

- Biogeochemical studies that jointly measure key parameters in coastal hypoxia dynamics, such as nutrients (e.g. C, N, Si, P, and Fe etc.), phytoplankton and microbes, will require specific investigations of typical hypoxic systems, such as coastal upwelling systems, areas off large rivers, and semi-enclosed basins. This, in conjunction with improved observational techniques, will indeed advance our knowledge of temporal and spatial controls on the occurrence and evolution of hypoxia and its impact on ecosystems across the global coastal ocean.

- It has been shown that the combined effect of low oxygen and high $\mathrm{CO}_{2}$ in the future ocean may cause a spatial expansion of OMZs and reduction of $\mathrm{O}_{2}$ to $\mathrm{CO}_{2}$ fugacity ratio (Brewer and Peltzer, 2009). Where the coastal hypoxia is fueled with low oxygen waters from open ocean, particularly in the "dead zones" of upwelling systems, the synergistic effect of low oxygen and high $p \mathrm{CO}_{2}$ on the evolution of coastal hypoxia will be more severe than previously predicted using models.

Despite its limited lifetime, SCOR Working Group \#128 was able to address the major issues of coastal hypoxia across different types of ecosystems within the global ocean (Table 3). The series of 10 papers in this Special Issue of Biogeosciences on "Coastal Hypoxia" provide a snap-shot of our experiences dealing with the global significance of coastal hypoxia under the influence of multiple natural (e.g. climate variability) and anthropogenic (e.g. nutrient loading from watersheds) stressors. Such an approach will contribute to our understanding of how marine ecosystem functions are affected by coastal hypoxia on time scales of a few years to thousands of years and on spatial scales from small estuaries and embayments to the global coastal ocean, as well as improving our confidence in the remediation measures applied to coastal hypoxia.

Acknowledgements. This manuscript was prepared based on extensive discussions among members of SCOR Working Group \#128 on "Natural and Human-Induced Hypoxia and Consequences for Coastal Areas" (2005-2010). The contribution of JZ in this work was supported by the Natural Science Foundation of China (No. 40721004) and the Ministry of Science and Technology of China through contract No. 2006CB400601, JM was supported by the EU (HYPOX). Support through SCOR was provided by the U.S. National Science Foundation Grant No. OCE-0608600. We express our sincere gratitude to C. Slomp, J. Carstensen and the anonymous reviewers for their constructive review comments and suggestions, which improved the original manuscript.

Edited by: C. P. Slomp

\section{References}

Aller, R. C.: Transport and reactions in the bioirrigated zone, edited by: Boudreau, B. P. and Jørgensen, B. B., The Benthic Boundary Layer: Transport Processes and Biogeochemistry, Oxford University Press, New York, pp. 269-301, 2001.

Amouroux, D., Roberts, G., Rapsomanikis, S., and Andreae, M. O.: Biogenic gas $\left(\mathrm{CH}_{4}, \mathrm{~N}_{2} \mathrm{O}\right.$, DMS $)$ emission to the atmosphere from near-shore and shelf waters of the north-western Black Sea, Est. Coast. Shelf Sci., 54, 575-587, 2002. 
Andrew, M. J. and Rickard, D. G.: Rehabilitation of the inner Thames Estuary, Mar. Poll. Bull., 11, 327-332, 1980.

Araujo, F. G., Bailey, R. G., and Williams, W. P.: Spatial and temporal variations in fish populations in the upper Thames Estuary, J. Fish Biol., 55, 836-853, 1999.

Arrigo, K. R.: Marine manipulations, Nature, 450, 491-492, 2007.

Bakun, A. and Weeks, S. J.: The marine ecosystem off Peru: What are the secrets of its fishery productivity and what might its future hold? Prog. Oceanogr., 79, 290-299, 2008.

Bange, H. W., Ramesh, R., Rapsomanikis, S., and Andreae, M. O.: Methane in surface waters of the Arabian Sea, Geophys. Res. Lett., 25, 3547-3550, 1998.

Bange, H. W., Andreae, M. O., Lal, S., Law, C. S., Naqvi, S. W. A., Patra, P. K., Rixen, T., and Upstill-Goddard, R. C.: Nitrous oxide emissions from the Arabian Sea: A synthesis, Atmos. Chem. Phys., 1, 61-71, 2001,

http://www.atmos-chem-phys.net/1/61/2001/.

Banse, K.: On upwelling and bottom trawling off the South west coast off India, J. Mar. Biol. Assoc. India, 1, 33-49, 1959.

Bender, M. A., Knutson, T. R., Tuleya, R. E., Sirutis, J. J., Vecchi, G. A., Barner, S. T., and Held, I. M.: Modeled impact of anthropogenic warning on the frequency of intense Atlantic hurricanes, Science, 327, 454-458, 2010.

Berner, U., Poggenburg, J., Faber, E., Quadfasel, D., and Frische, A.: Methane in ocean waters of the Bay of Bengal: Its sources and exchange with the atmosphere, Deep-Sea Res. Pt. II, 50, 925-950, 2003.

Bernhard, J. M. and Sen Gupta, B. K.: Foraminifera in oxygendepleted environments, edited by: Sen Gupta, B. K., Modern Foraminifera, Kluwer Academic Publishers, Dordrecht, pp 201216, 1999.

Bertrand, A., Gerlotto, F., Bertrand, S., Gutierrez, M., Alza, L., Chipollini, A., Diaz, E., Espinoza, P., Ledesma, P., Quesquen, R., Peraltilla, S., and Chavez, F.: Schooling behaviour and environmental forcing in relation to anchoveta distribution: An analysis across multiple spatial scales, Prog. Oceanogr., 79, 264-277, 2008.

Black Sea Commission: State of the Environment of the Black Sea (2001-2006/7), edited by: Oguz, T., The Commission on the Protection of the Black Sea against Pollution Publication, Istambul, Turkey, 448 pp, 2008.

Blauw, A. N., Hans, F. J. L., Bokhorst, M., and Erftemeijer, P. L. A.: GEM: A generic ecological model for estuaries and coastal waters, Hydrobiologia, 618(1), 175-198, 2009.

Boesch, D. F.: Challenges and opportunities for science in reducing nutrient over-enrichment of coastal ecosystems, Estuaries, 25, 886-900, 2002.

Bograd, S. J., Castro, C. G., Di Lorenzo, E., Palacios, D. M., Bailey, H., Gilly, W., and Chavez, F. P.: Oxygen declines and the shoaling of the hypoxic boundary in the California Current, Geophys. Res. Lett., 35, LI2607, doi:10.1029/2008GL034185, 2008.

Bonhomme, C., Aumont, O., and Echevin, V.: Advective transport caused by intra-seasonal Rossby waves: A key player of the high chlorophyll variability off the Peru upwelling region, J. Geophys. Res., 112, C09018, doi:10.1029/2006JC004022, 2007.

Boyle, E. A.: Anthropogenic trace elements in the ocean, edited by: Steel, J. H. and Turekian, K. K., Encyclopedia of Ocean Sciences, Academic Press, London, pp 162-169, 2001.

Brewer, P. G. and Peltzer, E.: Limits to marine life, Science, 324,
347-348, 2009.

Bricker, S. B., Clement, C. G., Pirhalla, D. E., Orlando, S. P., and Farrow, D. R. G.: National Estuarine Eutrophication Assessment: Effects of Nutrient Enrichment in the Nation's Estuaries, NOAA, National Ocean Service, Special Projects Office and the National Centers for Coastal Ocean Science, Silver Spring, MD, $71 \mathrm{pp}, 1999$.

Brongersma-Sanders, M.: Mass mortality in the sea, edited by: Hedgpeth, J. W., Treatise on Marine Ecology and Paleoecology, Vol. 1, Waverly Press, Baltimore, pp 941-1010, 1957.

Burdige, D.: Geochemistry of Marine Sediments, Princeton University Press, New Jersey, 593 pp, 2006.

Carruthers, J. N., Gogate, S. S., Naidu, J. R., and Laevastu, T.: Shoreward upslope of the layer of minimum oxygen off Bombay: Its influence on marine biology, especially fisheries, Nature, 183, 1084-1087, 1959.

Chan, F., Barth, J., Lubchenco, J., Kirincich, J., Weeks, A., Peterson, H., Mengl, W. T., and Chan, B. A.: Emergence of anoxia in the California Current Large Marine Ecosystem, Science, 319, p. 920, 2008.

Chen, C.-T.A. and Borges, A.V.: Reconciling opposing views on carbon cycling in the coastal ocean: Continental shelves as sinks and near-shore ecosystems as sources of atmospheric $\mathrm{CO}_{2}$, Deep-Sea Res. Pt. II, 56, 578-590, doi:10.1016/j.dsr2.2009.01.001, 2009.

Cloern, J. E.: Review our evolving conceptual model of the coastal eutrophication problem, Mar. Ecol. Prog. Ser., 210, 223-253, 2001.

Cockroft, A., Schoeman, D. S., Pitcher, G. C., Bailey, G. W., and van Zyl, D. C.: A mass stranding of west coast rock lobster Jasus lalandii in Elands Bay, South Africa: Causes, results and applications, edited by: Von Kaupel Klein, J. C. and Schram, F. R., The Biodiversity Crises and Crustaceans, Crustacean Issues, 11, 362-368, 2000.

Codispoti, L. A. and Christensen, J. P.: Nitrification, denitrification and nitrous oxide cycling in the eastern tropical South Pacific Ocean, Mar. Chem., 16, 277-300, 1985.

Codispoti, L. A., Elkins, J. W., Friederich, G. E., Packard, T. T., Sakamoto, C. M., and Yoshinari, T.: On the nitrous oxide flux from productive regions that contain low oxygen waters, edited by: Desai, B. N., Oceanography of the Indian Ocean, OxfordIBH, New Delhi, pp 271-284, 1992.

Cohen, Y. and Gordon, L. I.: Nitrous oxide in the oxygen minimum of the eastern tropical North Pacific: Evidence for its consumption during denitrification and possible mechanisms for its production, Deep-Sea Res. Pt. I, 25, 509-524, 1978.

Conley, D. J., Bjorck, S., Bonsdorff, E., Carstensen, J., Destouni, G., Gustafsson, B. G., Hietanen, S., Kortekaas, M., Kuosa, H., Meier, H. E. M., Muller-Karulis, B., Nordberg, K., Norkko, A., Nurnberg, G., Pitkanen, H., Rabalais, N. N., Rosenberg, R., Savchuk, O. P., Slomp, C. P., Voss, M., Wulff, F., and Zillen, L.: Hypoxia-related processes in the Baltic Sea, Environ. Sci. Technol., 43, 3412-3420, 2009a.

Conley, D. J., Carstensen, J., Vaquer-Sunyer, R., and Duarte, C. M.: Ecosystem thresholds with hypoxia, Hydrobiologia, 629, 21-29, 2009b.

Copenhagen, W. J.: The periodic mortality of fish in the Walvis region - a phenomenon within the Benguela Current, Investigational Report Division of Fisheries - Union of South Africa, 14, 
1-35, 1953.

Cornejo, M., Farías, L. and Gallegos, M.: Seasonal variability in $\mathrm{N}_{2} \mathrm{O}$ levels and air-sea $\mathrm{N}_{2} \mathrm{O}$ fluxes over the continental shelf waters off central Chile $\left(\sim 36^{\circ} \mathrm{S}\right)$, Prog. Oceanogr., 75, 383-395, 2007.

D'Andrea, A. F., Craig, N. I., and Lopez, G. R.: Benthic macrofauna and depth of bioturbation in Eckernfoerde Bay, Southwestern Baltic Sea, Geo-Mar. Lett., 16, 155-159, 1996.

De Bie, M. J. M., Middelburg, J. J., Starink, M., and Laanbroek, H. J.: Factors controlling nitrous oxide at the microbial community and estuarine scale, Mar. Ecol. Prog. Ser., 240, 1-9, 2002.

Deuser, W. G.: Reducing environments, edited by: Riley, J. P. and Chester, R., Chemical Oceanography, Academic Press, Vol. 3, London, pp 1-37, 1975.

Dewitte, B., Purca, S., Illig, S., Renault, L., and Giese, B. S.: Lowfrequency modulation of intraseasonal equatorial Kelvin wave activity in the Pacific from SODA: 1958-2001, J. Climate, 21, 6060-6069, 2008.

Diaz, R. J.: Interactive comment on "Effects of natural and humaninduced hypoxia on coastal benthos" by L. A. Levin et al., Biogeosciences Discuss., 6, C139-C143, 2009.

Diaz, R. J. and Rosenberg, R.: Marine benthic hypoxia: A review of its ecological effects and the behavioral responses of benthic macrofauna, Ann. Rev. Oceanogr. Mar. Biol., 33, 245-303, 1995.

Diaz, R. J. and Rosenberg, R.: Spreading dead zones and consequences for marine ecosystems, Science, 321, 926-929, 2008.

Doney, S. C., Tilbrook, B., Roy, S., Metzl, N., Le Quéré, C., Hood, M., Feely, R. A., and Bakker, D.: Surface-ocean $\mathrm{CO}_{2}$ variability and vulnerability, Deep-Sea Res. Pt. II, 56, 504-511, doi:10.1016/J.dsr2.2008.12.016, 2009.

Duce, R. A., LaRoche, J., Altieri, K., Arrigo, K. R., Baker, A. R., Capone, D. E., Cornell, S., Dentener, F., Galloway, J., Ganeshram, R. S., Geider, R. J., Jickells, T., Kuypers, M. M., Langlois, R., Liss, P. S., Liu, S. M., Middelburg, J. J., Moore, C. M., Nickovic, S., Oschlies, A., Pedersen, T., Prospero, J., Schlitzer, R., Seitzinger, S., Sorensen, L. L., Uematsu, M., Ulloa, O., Voss, M., Ward, B., and Zamora, L.: Impacts of atmospheric anthropogenic nitrogen on the open ocean, Science, 320, 893-897, 2008.

Dugdale, R. C., Goering, J. J., Barber, R. T., Smith, R. L., and Packard, T. T.: Denitrification and hydrogen sulfide in Peru upwelling during 1976, Deep-Sea Res. Pt. I, 24, 601-608, 1977.

Ekau, W., Auel, H., Pörtner, H.-O., and Gilbert, D.: Impacts of hypoxia on the structure and processes in the pelagic community (zooplankton, macro-invertebrates and fish), Biogeosciences Discuss., 6, 5073-5144, 2009, http://www.biogeosciences-discuss.net/6/5073/2009/.

Farías, L., Castro-González, M., Cornejo, M., Charpentier, J., Faúndez, J., Boontanon, N., and Yoshida, N.: Denitrification and nitrous oxide cycling within the upper oxycline of the oxygen minimum zone off the eastern tropical South Pacific, Limnol. Oceanogr., 54, 132-144, 2009.

Feely, R. A., Sabine, C. L., Hernandez-Ayon, J. M., and Ianson, D.: Evidence for upwelling of corrosive 'acidified' water onto the continental shelf, Science, 320, 1490-1492, 2008.

Fofonoff, P. and Millard Jr., R. C.: Algorithms for computation of fundamental properties of seawater, UNESCO Tech. Papers in Mar. Sci., 44, 53 pp., 1983.

Fonselius, S. and Valderrama, J.: One hundred years of hydro- graphic measurements in the Baltic Sea, J. Sea Res., 49, 229 241, doi:10.1016/S1385-1101(03)00035-2, 2003.

Garreaud, R. and Falvey, M.: The coastal winds off western subtropical South America in future climate scenarios, Int. J. Climatol., 29, 543-554, doi:10.1002/joc.1716, 2009.

Gerlach, S. A.: Nitrogen, phosphorus, plankton and oxygen deficiency in the German Bight and in Kiel Bay, Final Report, Eutrophication of the North Sea and the Baltic Sea, Kieler Meeresforschungen, Sonderheft, Nr. 7, 332 pp, 1990.

Gilbert, D., Sundby, B., Gobeil, C., Mucci, A., and Tremblay, G.H.: A seventy-two year record of diminishing deep-water oxygen in the St. Lawrence estuary: The northwest Atlantic connection, Limnol. Oceanogr., 50, 1654-1666, 2005.

Gilbert, D., Rabalais, N. N., Diaz, R. J., and Zhang, J.: Evidence for greater oxygen decline rates in the coastal ocean than in the open ocean, Biogeosciences Discuss., 6, 9127-9160, 2009, http://www.biogeosciences-discuss.net/6/9127/2009/.

Glazer, B. T., Luther, G. W., Konovalov, S. K., Friederich, G. E., Trouwborst, R. E., and Romanov, A. S.: Spatial and temporal variability of the Black Sea suboxic zone, Deep-Sea Res. Pt. II, 53, 1756-1768, 2006.

Glud, R. N.: Oxygen dynamics of marine sediments, Mar. Biol. Res., 4, 243-289, 2008.

Gooday, A. J.: Benthic foraminifera (Protista) as tools in deepwater palaeoceanography: A review of environmental influences on faunal characteristics, Adv. Mar. Biol., 46, 1-90, 2003.

Gooday A. J., Jorissen, F., Levin, L. A., Middelburg, J. J., Naqvi, S. W. A., Rabalais, N. N., Scranton, M., and Zhang, J.: Historical records of coastal eutrophication-induced hypoxia, Biogeosciences, 6, 1707-1745, 2009,

http://www.biogeosciences.net/6/1707/2009/.

Grantham, B. A., Chan, F., Nielsen, K. J., Fox, D. S., Barth, J. A., Huyer, A., Lubchenco, J., and Menge, B. A.: Upwellingdriven near-shore hypoxia signals ecosystem and oceanographic changes in the northeast Pacific, Nature, 429, 749-754, 2004.

Green, M. A. and Aller, R. C.: Early diagenesis of calcium carbonate in Long Island Sound sediments: Benthic fluxes of $\mathrm{Ca}^{2+}$ and minor elements during seasonal periods of net dissolution, J. Mar. Res., 59, 769-794, 2001.

Gregoire, M. and Lacroix, G.: Study of the oxygen budget of the Black Sea waters using a 3-D coupled hydrodynamicalbiogeochemical model, J. Mar. Syst., 31, 175-202, 2001.

Gutierrez, D., Enriquez, E., Purca, S., Quipuzcoa, L., Marquina, R., Flores, G., and Graco, M.: Oxygenation episodes on the continental shelf of central Peru: Remote forcing and benthic ecosystem response, Prog. Oceanogr., 79, 177-189, 2008.

Hagy, J. D., Boynton, W. R., Keefe, C. W., and Wood, K. V.: Hypoxia in Chesapeake Bay, 1950-2001: Long-term change in relation to nutrient loading and river flow, Estuaries, 27, 634-658, 2004.

Hanninen, J., Vuorinen, I., and Hjelt, P.: Climatic factors in the Atlantic control the oceanographic and ecological changes in the Baltic Sea, Limnol. Oceanogr., 45, 703-710, 2000.

Howarth, R. W., Sharpley, A., and Walker, D.: Sources of nutrient pollution to coastal waters in the United States: Implications for achieving coastal water quality goals, Estuaries, 25, 656-676, 2002.

IPCC: Climate Change 2007: Synthesis Report, Contribution of Working Groups I, II, and III to the Fourth Assessment Report 
of the Intergovernmental Panel on Climate Change [Core Writing Team, edited by: Pachauri, R. K. and Reisinger, A.], IPCC, Geneva, Switzerland, 104 pp, 2007a.

Intergovernmental Panel on Climate Change (IPCC): Climate Change 2007 - Impacts, Adaptation and Vulnerability. Contribution of Working Group II to the Fourth Assessment Report of the Intergovernmental Panel on Climate, Change, edited by: Parry, M. L., Canziani, O. F. Palutikof, J. P., van der Linden, P. J., and Hanson, C. E., Cambridge University Press, Cambridge, UK, 976 pp., $2007 b$.

Jayakumar, D. A., Naqvi, S. W. A., Narvekar, P. V., and George, M. D.: Methane in coastal and offshore waters of the Arabian Sea, Mar. Chem., 74, 1-13, 2001.

Jennings, S. and Wilson, R.: Fishing impacts on the marine inorganic carbon cycle, J. Appl. Ecol., 46, 976-982, 2009.

Jørgensen, B. B.: Mineralization of organic matter in the sea bed The role of sulphate reduction, Nature, 296, 643-645, 1982.

Jørgensen, B. B.: Seasonal oxygen depletion in the bottom waters of a Danish fjord and its effect on the benthic community, Oikos, 34, 68-76, 1980.

Jorissen, F. J.: Benthic foraminiferal microhabitats below the sediment-water interface, edited by: Sen Gupta, B. K., Modern Foraminifera, Kluwer Academic Publishers, Dordrecht, pp 161$179,1999$.

Jorissen, F. J., Wittling, I., Peypouquet, J. P., Rabouille, C., and Relexans, J. C.: Live benthic foraminiferal faunas off Cap Blanc, NW Africa: Community structure and microhabitats. Deep-Sea Res. Pt. I, 45, 2157-2188, 1998.

Justić, D., Legović, T., and Rottini-Sandri, L.: Trends in oxygen content 1911-1984 and occurrence of benthic mortality in the northern Adriatic Sea, Est. Coast. Shelf Sci., 25, 435-445, 1987.

Justić, D., Rabalais, N. N., and Turner, R. E.: Simulated response of the Gulf of Mexico hypoxia to variations in climate and anthropogenic nutrient loading, J. Mar. Syst., 42, 115-126, 2003.

Karl, D. M., Beversdorf, L., Bjoerkman, K. M., Church, M. J., Martinez, A., and DeLong, E. F.: Aerobic production of methane in the sea, Nat. Geosci., 1, 473-478, 2008.

Karstensen, J., Stramma, L., and Visbeck, M.: Oxygen minimum zones in the eastern tropical Atlantic and Pacific oceans, Prog. Oceanogr., 77, 331-350, doi:10.1016/j.pocean.2007.05.009, 2008.

Keeling, R. F., Körtzinger, A. K., and Gruber, N.: Ocean deoxygenation in a warming world, Ann. Rev. Mar. Sci., 2, 199-229, 2010.

Kelley, C.: Methane oxidation potential in the water column of two diverse coastal marine sites, Biogeochemistry, 65, 105-120, 2003.

Kemp, W. M., Boynton, W. R., Adolf, J., Boesch, D., Boicourt, W., Brush, G., Cornwell, J., Fisher, T., Glibert, P., Hagy, J., Harding, L., Houde, E., Kimmel, D., Miller, W. D., Newell, R. I. E., Roman, M., Smith, E., and Stevenson, J. C.: Eutrophication of Chesapeake Bay: Historical trends and ecological interactions, Mar. Ecol. Prog. Ser., 303, 1-29, 2005.

Kemp, W. M., Testa, J. M., Conley, D. J., Gilbert, D., and Hagy, J. D.: Temporal responses of coastal hypoxia to nutrient loading and physical controls, Biogeosciences, 6, 2985-3008, 2009, http://www.biogeosciences.net/6/2985/2009/.

Kennett, J. P. and Ingram, B. L.: A 20,000 year record of ocean circulation and climate-change from the Santa Barbara Basin, Na- ture, 377, 510-514, 1995.

Knutson, T. R., Sirutis, J. J., Garner, S. T., Held, I. M., and Tuley, R. E.: Simulation of the recent multi-decadal increase of Atlantic hurricane activity using an 18-km-grid regional model, Bull. Am. Meteorol. Soc., 88, 1549-1565, 2007.

Kock, A., Gebhardt, S., and Bange, H. W.: Methane emissions from the upwelling area off Mauritania (NW Africa), Biogeosciences, 5, 1119-1125, 2008, http://www.biogeosciences.net/5/1119/2008/.

Kuypers, M. M. M., Lavik, G., Woebken, D., Schmid, M., Fuchs, B. M., Amann, R., Jørgensen, B. B., and Jetten, M. S. M.: Massive nitrogen loss from the Benguela upwelling system through anaerobic ammonium oxidation, PNAS, 102, 6478-6483, 2005.

Lass, H. U. and Mohrholz, V.: On the interaction between the sub-tropical gyre and the sub-tropical cell on the shelf of the SE Atlantic, J. Mar. Syst., 74, 1-43, doi:10.1016j.j.marsys.2007.09.008, 2008.

Lavik, G., Stuhrmann, T., Brüchert, V., Van der Plas, A., Mohrholz, V., Lam, P., Mussmann, M., Fuchs, B. M., Amann, R., Lass, U., and Kuypers, M. M. M.: Detoxification of sulphidic African shelf waters by blooming chemolithotrophs, Nature, 457, 581586, 2009.

Levin, L. A.: Oxygen minimum zone benthos: Adaptation and community response to hypoxia, Ann. Rev. Oceanogr. Mar. Biol., 41, 1-45, 2003.

Levin, L. A., Ekau, W., Gooday, A. J., Jorissen, F., Middelburg, J. J., Naqvi, S. W. A., Neira, C., Rabalais, N. N., and Zhang, J.: Effects of natural and human-induced hypoxia on coastal benthos, Biogeosciences, 6, 2063-2098, 2009, http://www.biogeosciences.net/6/2063/2009/.

Li, D. J., Zhang, J., Huang, D. J., Wu, Y., and Liang, J.: Oxygen depletion off the Changjiang (Yangtze River) Estuary, Sci. China, 45, 1137-1146, 2002.

Matear, R. J. and Hirst, A. C.: Long-term changes in dissolved oxygen concentrations in the ocean caused by protracted global warming, Global Biogeochem. Cy., 17(4), 1125, doi:10.1029/2002GB001997, 2003.

Meysman, F. J. R., Boudreau, B. P., and Middelburg, J. J.: Modeling reactive transport in sediments subject to bioturbation and compaction, Geochim. Cosmochim. Acta., 69, 3601-3617, 2005.

Meysman, F. J. R., Middelburg, J. J., and Heip, C. H. R.: Bioturbation: A fresh look at Darwin's last idea, Trends Ecol. Evol., 21, 688-695, 2006.

Meysman, F. J. R., Malyuga, V. S., Boudreau, B. P., and Middelburg, J. J.: A generalized stochastic approach to particle dispersal in soils and sediments, Geochim. Cosmochim. Acta., 72, 34603478, 2008.

Middelburg, J. J. and Levin, L. A.: Coastal hypoxia and sediment biogeochemistry, Biogeosciences, 6, 1273-1293, 2009, http://www.biogeosciences.net/6/1273/2009/.

Milliman, J. D., Farnsworth, K. L., Jones, P. D., Xu, K. H., and Smith, L. C.: Climatic and anthropogenic factors affecting river discharge to the global ocean, 1951-2000, Global Planet. Change, 62, 187-194, 2008.

Minami, H., Kano, Y., and Ocawa, K.: Long-term variations of potential temperature and dissolved oxygen of the Japan Sea proper water, J. Oceanogr., 55, 197-205, 1999.

Mirza, P. B. and Gray, J. S.: The fauna of benthic sediments from the organically enriched Oslofjord, Norway, J. Exper. Mar. Biol. 
Ecol., 54, 181-207, 1981.

Mohrholz, V., Bartholomae, C. H., van der Plas, A. K., and Lass, H. U.: The seasonal variability of the northern Benguela undercurrent and its relation to the oxygen budget on the shelf, Cont. Shelf Res., 28, 424-441, doi:10.1016/j.csr.2007.10.001, 2008.

Monteiro, P. M. S., Van der Plas, A. K., Mohrholz, V., Mabille, E., Pascall, A., and Joubert, W.: Variability of natural hypoxia and methane in a coastal upwelling system: Oceanic physics or shelf biology? Geophys. Res. Lett., 33, L16614, doi:10.1029/2006GL026234, 2006a.

Monteiro, P. M. S., Van der Plas, A. K., Bailey, G. W., MalanotteRizzoli, P., Duncombe Rae, C. M., Byrnes, D., Pitcher, G., Florenchie, P., Penven, P., Fitzpatrick, J., and Lass H. U.: Low oxygen water (LOW) forcing scales amenable to forecasting in the Benguela Ecosystem, edited by: Shannon, V., Hempel, G., Malanotte-Rizzoli, P., Moloney, C., and Woods, J., The Benguela: Predicting A Large Marine Ecosystem, vol. 14 (13), Elsevier, New York, pp 303-316, 2006 b.

Monteiro, P. M. S., Van der Plas, A. K., Melice, J.-L., and Florenchie, P.: Interannual hypoxia variability in a coastal upwelling system: Ocean-shelf exchange, climate and ecosystem-state implications. Deep-Sea Res. Pt. I, 435-450, 2008.

Naik, H., Naqvi, S. W. A., Suresh, T., and Narvekar, P. V.: Impact of a tropical cyclone on biogeochemistry of the central Arabian Sea, Global Biogeochem. Cy., 22, GB3020, doi:10.1029/ 2007GB003028, 2008.

Naqvi, S. W. A., Jayakumar, D. A., Nair, M., George, M. D., and Kumar, M. D.: Nitrous oxide in the western Bay of Bengal, Mar. Chem., 47, 269-278, 1994.

Naqvi, S. W. A., Jayakumar, D. A., Narvekar, P. V., Naik, H., Sarma, V. S., D’Souza, W., Joseph, T., and George, M. D.: Increased marine production of $\mathrm{N}_{2} \mathrm{O}$ due to intensifying anoxia on the Indian continental shelf, Nature, 408, 346-349, 2000.

Naqvi, S. W. A., Bange, H. W., Gibb, S. W., Goyet, C., Hatton, A. D., and Upstill-Goddard, R. C.: Biogeochemical oceanatmosphere transfers in the Arabian Sea, Prog. Oceanogr., 65, 116-144, 2005.

Naqvi, S. W. A., Naik, H., Pratihary, A., D’Souza, W., Narvekar, P. V., Jayakumar, D. A., Devol, A. H., Yoshinari, T., and Saino, T.: Coastal versus open-ocean denitrification in the Arabian Sea, Biogeosciences, 3, 621-633, 2006, http://www.biogeosciences.net/3/621/2006/.

Naqvi, S. W. A., Bange, H. W., Faras, L., Monteiro, P. M. S., Scranton, M. I., and Zhang, J.: Coastal hypoxia/anoxia as a source of $\mathrm{CH}_{4}$ and $\mathrm{N}_{2} \mathrm{O}$, Biogeosciences Discuss., 6, 9455-9523, 2009, http://www.biogeosciences-discuss.net/6/9455/2009/.

Nevison, C. D., Lueker, T. J., and Weiss, R. F.: Quantifying the nitrous oxide source from coastal upwelling, Global Biogeochem. Cy., 18, GB1018, doi:10.1029/2003GB002110, 2004.

Nissling, A., and Westin, L.: Salinity requirements for successful spawning of Baltic and Belt Sea cod and the potential for cod stock interactions in the Baltic Sea, Mar. Ecol. Prog. Ser., 152, 261-271, 1997.

Nixon, S. W.: The artificial Nile, Am. Sci., 94, 158-165, 2004.

Oguz, T., Ducklow, H., and Malanotte-Rizzoli, P.: Modelling distinct vertical biogeochemical structure of the Black Sea: Dynamic coupling of oxic, suboxic and anoxic layers, Global Biogeochem. Cy., 14, 1331-1352, 2000.

Oschlies, A., Schulz, K. G., Riebesell, U., and Schmittner, A.:
Simulated 21st Century's increase in oceanic suboxia by $\mathrm{CO}_{2}-$ enhanced biotic carbon export, Global Biogeochem. Cy., 22, GB4008, doi:10.1029/2007GB003147, 2008.

Patcirck, R.: Changes in the chemical and biological characteristics of the Upper Delware River Estuary in response to environmental laws, edited by: Majumdar, E., Miller, E., and Sage, L. E., Pennsylvania Academy of Sciences, Philadelphia PA, pp 323359, 1988.

Parker, C. A. and O'Reilly, J. E.: Oxygen depletion in Long Island Sound: A historical perspective, Estuaries, 14, 248-264, 1991.

Paulmier, A. and Ruiz-Pino, D.: Oxygen Minimum Zones (OMZs) in the Modern Ocean, Prog. Oceanogr., 80, 113-128, doi:10.1016/j.pocean.2008.05.001, 2009.

Peña, M. A., Katsev, S., Oguz, T., and Gilbert, D.: Modeling dissolved oxygen dynamics and hypoxia, Biogeosciences, 7, 933957, 2010,

http://www.biogeosciences.net/7/933/2010/.

Petersen, C. G. J.: On the animal communities of the sea bottom in the Skagerak, the Christiania Fjord and the Danish waters, Report from the Danish Biological Station, 23, 1-28, 1915.

Pizarro, O., Shaffer, G., Dewitte, B., and Ramos, M.: Dynamics of seasonal and interannual variability of the PeruChile undercurrent, Geophys. Res. Lett., 29(12), 1581, doi:10.1029/2002GL014790, 2002.

Pörtner, H.-O. and Knust, R.: Climate change affects marine fishes through the oxygen limitation of thermal tolerance, Science, 315 , 95-97, 2007.

Pörtner, H.-O. and Farrell, A. P.: Physiology and Climate Change, Science, 322, 690-692, 2008.

Rabalais, N. N., Turner, R. E., and Wiseman Jr., W. J.: Hypoxia in the Gulf of Mexico, J. Environ. Qual., 30, 320-329, 2001.

Rabalais, N. N., Turner, R. E., and Scavia, D.: Beyond science into policy: Gulf of Mexico hypoxia and the Mississippi River, BioScience, 52, 129-142, 2002.

Rabalais, N. N., Turner, R. E., Sen Gupta, B. K., Boesch, D. F., Chapman, P., and Murrell, M. C.: Characterization and longterm trends of hypoxia in the northern Gulf of Mexico: Does the science support the Action Plan? Estuar. Coasts, 30, 753-772, 2007.

Rabalais, N. N. and Gilbert, D.: Distribution and consequences of hypoxia, edited by: Urban Jr., E. R., Sundby, B., MalanotteRizzoli, P., and Melillo, J. M., Watersheds, Bays, and Bounded Seas, Island Press, Washington DC, pp 209-225, 2009.

Rabalais, N. N., Turner, R. E., Díaz, R. J., and Justić, D.: Climate change and eutrophication of coastal waters, ICES J. Mar. Sci., 66, 1528-1537, 2009.

Rabalais, N. N., Díaz, R. J., Levin, L. A., Turner, R. E., Gilbert, D., and Zhang, J.: Dynamics and distribution of natural and humancaused hypoxia, Biogeosciences, 7, 585-619, 2010, http://www.biogeosciences.net/7/585/2010/.

Rabouille, C., Conley, D. J., Dai, M. H., Cai, W.-J., Chen, C. T. A., Lansard, B., Green, R., Yin, K., Harrison, P. J., Dagg, M., and Mckee, B.: Comparison of hypoxia among four river-dominated ocean margins: The Changjiang (Yangtze), Mississippi, Pearl, and Rhone rivers, Cont. Shelf Res., 28, 1527-1537, 2008.

Reeburgh, W. S.: Oceanic methane biogeochemistry, Chem. Rev., 107, 486-513, 2007.

Renault, L., Dewitte, B., Falvey, M., Garreaud, R., Echevin, V., and Bonjean, F.: Impact of atmospheric coastal jets 
off central Chile on sea surface temperature from satellite observations (2000-2007), J. Geophys. Res., 114, C08006, doi:10.1029/2008JC005083, 2009.

Richardson, A. J. and Poloczanska, E. S.: Under-resourced, under threat, Science, 320, 1294-1295, 2008.

Riebesell, U., Schulz, K., Bellerby, R., Botros, M., Fritsche, P., Meyerhofer, M., Neill, C., Nondal, G., Oschlies, A., Wohlers, J., and Zollner, E.: Enhanced biological carbon consumption in a high $\mathrm{CO}_{2}$ ocean, Nature, 450, 545-548, 2007.

Rönner, U.: Distribution, production and consumption of nitrous oxide in the Baltic Sea, Geochim. Cosmochim. Acta, 47, 21792188, 1983.

Rosenberg, R.: Negative oxygen trends in Swedish coastal bottom waters, Mar. Poll. Bull., 21, 335-339, 1990.

Rosenberg, R., Gray, J. S., Josefson, A. B., and Pearson, T. H.: Petersen's benthic stations revisited. II. Is the Oslofjord and eastern Skagerrak enriched? J. Exper. Mar. Ecol., 105, 219-251, 1987.

Rouault, M., Illig, S., Bartholomae, C., Reason C. J. C., and Bentamy, A.: Propagation and origin of warm anomalies in the Angola Benguela upwelling system in 2001. J. Mar. Syst., 68, 473488, 2007.

Sale, J. W. and Skinner, W.W.: The vertical distribution of dissolved oxygen and the precipitation of salt water in certain tidal areas, Franklin Inst. J., 184, 837-848, 1917.

Sansone, F. J., Popp, B. N., Gasc, A., Graham, A. W., and Rust, T. M.: Highly elevated methane in the eastern tropical North Pacific and associated isotopically enriched fluxes to the atmosphere, Geophys. Res. Lett, 28, 4567-4570, 2001.

Sansone, F. J., Graham, A. W., and Berelson, W. M.: Methane along the western Mexican margin, Limnol. Oceanogr., 49, 22422255, 2004.

Santana-Casiano, J. M., Gonzalez-Davila, M., and Ucha., I. R.: Carbon dioxide fluxes in the Benguela upwelling system during winter and spring: A comparison between 2005 and 2006, Deep-Sea Res. Pt. II, 56, 533-541, doi:10.1016/j.dsr2.2008.12.010, 2009.

Schulz, H. N. and Jørgensen, B. B.: Big bacteria, Ann. Rev. Microbiol., 55, 105-137, 2001.

Scranton, M. I. and Brewer, P. G.: Occurrence of methane in nearsurface waters of western subtropical North Atlantic, Deep-Sea Res. Pt. I, 24, 127-138, 1977.

Scranton, M. I. and Farrington, J. W.: Methane production in waters off Walvis Bay, J. Geophys. Res., 82, 4947-4953, 1977.

Seitzinger, S. P., Kroeze, C., Bouwman, A. E., Caraco, N., Dentener, F., and Styles, R. V.: Global patterns of dissolved inorganic and particulate nitrogen inputs to coastal systems, Estuaries, 25, 640-655, 2002.

Shaffer, G., Olsen, S. M., and Pederson, J. O. P.: Long-term ocean oxygen depletion in response to carbon dioxide emissions from fossil fuels, Nat. Geosci., 2, 105-109, 2009.

Soetaert, K. and Middelburg, J. J.: Modeling eutrophication and oligotrophication of shallow-water marine systems: The importance of sediments under stratified and well mixed conditions, Hydrobiologia, 629, 239-254, 2009.

Solomon, E. A., Kastner M., MacDonald I. R., and Leifer, I.: Considerable methane fluxes to the atmosphere from hydrocarbon seeps in the Gulf of Mexico, Nat. Geosci., 2, 561-565, doi:10.1038/NGEO574, 2009.

Stramma, L., Johnson, G. C., Sprintall, J., and Mohrholz, V.: Expanding oxygen-minimum zones in the tropical oceans, Science,
320, 655-658. 2008.

Stramma, L., Schmidt, S., Levin, L. A., and Johnson, G. C.: Ocean oxygen minima expansions and their biological impacts, DeepSea Res. Pt. I, 57, 587-595, 2010.

Taguchi, F. and Fujiwara, T.: Carbon dioxide stored and acidified low oxygen bottom waters in coastal sea, Japan, Est. Coast. Shelf Sci., 86, 429-433, 2009.

Tett, P., Gowen, R., Mills, D., Fernandes, T., Gilpin, L., Huxham, M., Kennington, K., Read, P., Service, M., Wilkinson, M., and Malcolm, S.: Defining and detecting undesirable disturbance in the context of marine eutrophication, Mar. Poll. Bull., 55, 282297, 2007.

Turner, R. E. and Rabalais, N. N.: Coastal eutrophication near the Mississippi River delta, Nature, 368, 619-621, 1994.

Turner, R. E., Rabalais, N. N., and Justic, D.: Gulf of Mexico hypoxia alternate states and a legacy, Environ. Sci. Technol., 42, 2323-2327, 2008.

Van de Koppel, J., Tett, P., Naqvi, W., Oguz, T., Perillo, G. M. E., Rabalais, N., d'Alcala, M. R., Su, J. L., and Zhang, J.: Threshold effects in semi-enclosed marine systems, edited by: Urban Jr., E. R., Sundby, B., Malanotte-Rizzoli, P., and Melillo, J. M., Watersheds, Bays, and Bounded Seas, SCOPE 70, Island Press, Washington DC, pp 31-47, 2009.

Vaquer-Sunyer, R. and Duarte, C. M.: Thresholds of hypoxia for marine biodiversity, PNAS, 105, 15452-15457, 2008.

Vecchi, G. A., Soden, B. J., Wittenberg, A. T., Held, I. M., Leetmaa, A., and Harrison, M. J.: Weakening of tropical Pacific atmospheric circulation due to anthropogenic forcing, Nature, 441, 73-76, 2006.

Waldbusser, G. G., Marinelli, R. L., Whitlatch, R. B., and Visscher, P. T.: The effects of infaunal biodiversity on biogeochemistry of coastal marine sediments, Limnol. Oceanogr., 49, 1482-1492, 2004.

Weeks, S. J., Currie, B., and Bakun, A.: Satellite imaging: Massive emissions of toxic gas in the Atlantic, Nature, 415, 493-494, 2002.

Weeks, S. J., Currie, B., Bakun, A., and Peard, K. R.: Hydrogen sulphide eruptions in the Atlantic Ocean off southern Africa: Implications of a new view based on SeaWiFS satellite imagery. Deep-Sea Res. Pt. I, 51, 153-172, 2004.

Wu, Y., Dittmar, T., Ludwichowski, K. U., Kettner, G., Zhang, J., Zhu, Z. Y., and Koch B. P.: Tracing suspended organic nitrogen from the Yangtze River catchment into the East China Sea, Mar. Chem., 107, 367-377, 2007.

Yamagishi, H., Westley, M. B., Popp, B. N., Toyoda, S., Yoshida, N., Watanabe, S., Koba, K., and Yamanaka, Y.: Role of nitrification and denitrification on the nitrous oxide cycle in the eastern tropical North Pacific and Gulf of California, J. Geophys. Res., 112, G02015, doi:10.1029/2006JG000227, 2007.

Yeh, S.-W., Kug, J.-S., Dewitte, B., Kwon, M.-H., Kirtman, B.P., and Jin, F.-F.: El Niño in a changing climate, Nature, 461, 511514, 2009.

Yin, K. D., Lin, Z. F., and Ke, Z. Y.: Temporal and spatial distribution of dissolved oxygen in the Pearl River Estuary and adjacent coastal waters, Cont. Shelf Res., 24, 1935-1948, 2004.

Zaitsev, Y.: Ecological state of the Black Sea shelf zone, Ukrainian coast (a review), Gidrobiolog. Zhurnal (in Russian), 28(4), 3-18, 1992.

Zaitsev, Y. and Mamaev, V.: Marine biological diversity in the Black 
Sea: A study of change and decline, United Nations Publications, New York, 208 pp, 1997.

Zhang, G. L., Zhang, J., Ren, J. L., Li, J. B., and Liu, S. M.: Distribution and sea-to-air fluxes of methane and nitrous oxide in the North East China Sea in summer, Mar. Chem., 110, 42-55, 2008.
Zhang, J., Liu, S. M., Ren, J. L., Wu, Y., and Zhang, G. L.: Nutrient gradients from the eutrophic Changjiang (Yangtze River) Estuary to the oligotrophic Kuroshio waters and re-evaluation of budgets for the East China Sea Shelf, Prog. Oceanogr., 74, 449478, 2007. 